\title{
NANOPARTIKEL SENG OKSIDA (ZnO) DARI BIOSINTESIS EKSTRAK RUMPUT LAUT COKLAT Sargassum sp. DAN Padina sp.
}

\section{Zinc Oxide Nanoparticles (ZnO) from Biosynthesis of Sargassum sp. and Padina sp. Brown Seaweed Extract}

\author{
Rodiah Nurbaya Sari*, Ekowati Chasanah, dan Nurhayati \\ Balai Besar Riset Pengolahan Produk dan Bioteknologi Kelautan dan Perikanan, \\ JI. KS Tubun Petamburan VI, Slipi, Jakarta, Indonesia \\ *Korespondensi Penulis: rnurbayasari@gmail.com
}

Diterima: 28 September 2017; Direvisi: 29 Desember 2017; Disetujui: 6 Juni 2018

\begin{abstract}
ABSTRAK
Pemanfaatan rumput laut untuk disintesis secara biologi (biosintesis) menjadi nanopartikel logam telah banyak dilakukan sebagai alternatif produksi ramah lingkungan. Penelitian ini bertujuan mendapatkan nanopartikel seng oksida $(\mathrm{ZnO})$ melalui biosintesis ekstrak rumput laut coklat Sargassum sp. dan Padina sp. dengan menggunakan prekursor zink nitrat $10 \mathrm{mM}$ pada variasi $\mathrm{pH}$ larutan 8-12. Analisis meliputi gugus fungsi, distribusi ukuran partikel, morfologi, dan kristalinitas. Hasil penelitian menunjukkan gugus fungsi hidroksil dan sulfat polisakarida berperan dalam proses reduksi kation $\mathrm{Zn}^{2+}$ membentuk nanopartikel $\mathrm{ZnO}$ sedangkan protein untuk kestabilan nano-partikel. Nanopartikel ZnO dari biosintesis ekstrak Sargassum sp. dan Padina sp. masing-masing menghasilkan rata-rata ukuran partikel berkisar antara 1.396,53-3.090,50 dan 655,91-3.253,06 nm. Distribusi ukuran sudah homogen namun belum memenuhi besaran ukuran nanometer. Rata-rata ukuran partikel terkecil terdapat pada $\mathrm{pH} 10$ dan 9. Kisaran \% mass elemen $\mathrm{Zn}$ dan $\mathrm{O}$ nanopartikel $\mathrm{ZnO}$ biosintesis ekstrak Sargassum sp. yang mirip standar adalah pada $\mathrm{pH} 10$ yaitu 95,98\% dan 4,02\% sedangkan dari ekstrak Padina sp. pada pH 9 dengan $94,67 \%$ dan 5,33\%. Struktur kristalinitas menunjukkan ZnO biosintesis ekstrak Sargassum sp. pada $\mathrm{pH}$ 8-11 dan Padina sp. pada pH 9 hampir seluruhnya memiliki puncak dengan nilai sudut $2 \theta$ yang hampir sama, dan setelah dikonfirmasi dengan program Match! 3 menunjukkan struktur kristal ZnO wurtzit berbentuk heksagonal. Perlakuan terbaik $\mathrm{ZnO}$ biosintesis dari ekstrak Sargassum sp. dan Padina sp. adalah pada kondisi $\mathrm{pH} 10$ dan 9 .
\end{abstract}

KATA KUNCI: biosintesis, ekstrak Sargassum sp., ekstrak Padina sp., nanopartikel, ZnO

\begin{abstract}
Biosynthesis of metal nanoparticles using seaweed became an important area in the field of nanotechnology which has economic and eco-friendly benefits. This research aimed to obtain zinc oxide nanoparticles (ZnO NPs) through biosynthesis of extract brown seaweed Sargassum sp. and Padina sp. using $10 \mathrm{mM}$ zinc nitrate as precursor at various $\mathrm{pH}$ of 8-12. Analysis of $\mathrm{ZnO} \mathrm{NPs}$ covered functional groups, particle size distribution, morphology, and crystallinity. The result showed that hydroxyl groups and sulfate polysaccharide played role in the formation of ZnO NPs while protein contributed on stabilizing of the nanoparticles. Analysis showed that the size of ZnO NPs biosynthesized Sargassum sp. extract was from 1,396.53 to 3,090.50 nm and 655.91 to 3,253.06 $\mathrm{nm}$ for Padina sp. The size qualification particle distribution was homogeneous but their size has not yet met for nanoparticles size standard. Average of the smallest particle size was found at $\mathrm{pH} 10$ and 9 treatments. Distribution of $\mathrm{Zn}$ and $\mathrm{O}$ elements of $\mathrm{ZnO}$ biosynthesized Sargassum sp. extract which was similar to the standard was at $\mathrm{pH} 10$ with $95.98 \%$ and 4.02 of \% mass, while that of Padina sp. extract at $\mathrm{pH} 9$ with $94.67 \%$ and $5.33 \%$ respectively. The crystallity structure showed that $\mathrm{ZnO}$ biosynthesis of Sargassum sp. and Padina sp. extract performed at $\mathrm{pH}$ 8-11 and $\mathrm{pH}$ 9, respectively, had similar $2 \theta$ angle peak. A hexagonal shape of $\mathrm{ZnO}$ wurtzite crystalline structure has formed and it confirmed by Match! program 3. The best treatment of $\mathrm{ZnO}$ biosynthesis process for Sargassum sp and Padina sp.so extract was at pH 10 and 9, respectively.
\end{abstract}

Keywords: biosynthesis, Sargassum sp. extract, Padina sp. extract, nanoparticles, ZnO

Copyright @ (2018, JPBKP, Nomor Akreditasi : 769/AU3/P2MI-LIPI/08/2017

DOI : http://dx.doi.org/10.15578/jpbkp.v13i1.489 


\section{PENDAHULUAN}

Penelitian berbasis teknologi nano (nanotechnology) kini berkembang pesat dan terus dilakukan oleh para peneliti baik dari dunia akademik maupun industri. Prinsip teknologi nano adalah merekayasa sifat-sifat dan performansi material sedemikian rupa hingga menjadi lebih efektif, efisien, dan berdaya guna lebih. Nanopartikel memiliki ukuran partikel yang sangat kecil yaitu 1-100 nm sehingga nanopartikel memiliki karakteristik fisika, kimia, dan biologi yang unik, yang jauh berbeda dibandingkan dengan material ukuran besarnya. Penelitian di bidang nanoteknologi telah menunjukkan terciptanya produk-produk baru dengan kinerja yang lebih baik. Nanopartikel dapat diaplikasikan dalam berbagai bidang, seperti bidang kesehatan, lingkungan, pertanian, pangan, tekstil, industri kosmetik, elektronika, dan energi. Kegunaan tersebut antara lain sebagai antibakteri, detektor, katalis dan zat pelapis pada permukaan (Ristian, 2013).

Sintesis nanopartikel dapat dilakukan dengan tiga metode yaitu kimia (bottom-up), fisika (top-down), dan biologi (biosynthesis). Dari ketiga metode tersebut, biosintesis dapat menjadi alternatif produksi nanopartikel yang ramah lingkungan (green synthesis). Biosintesis nanopartikel menggunakan rumput laut telah banyak dikembangkan saat ini, karena kandungan fitokimia termasuk hidroksil, karboksil, dan kelompok fungsional amino dapat menyediakan logam-reduktor yang efektif maupun sebagai agen pengikat untuk memberikan lapisan yang kuat pada nanopartikel logam dalam satu langkah. Unsur logam yang salah satunya terdapat dalam rumput laut adalah zink ( $Z n$ ). Jumlah unsur $Z n$ ini dalam rumput laut berbeda-beda untuk tiap jenis dan lokasi tumbuh rumput laut. Hasil peneltian Krishnaiah, Sarbatly, Prasad, dan Bono (2008) dan Manivannan, Devi, Thirumaran, dan Anantharaman (2008) menunjukkan kadar $\mathrm{Zn}$ rumput laut coklat (Turbinaria ornata, Padina gymnospora, dan Sargassum sp.) berkisar antara 0,34-1,3 mg/kg.

Hasil penelitian mengenai biosintesis nanopartikel $\mathrm{ZnO}$ dari rumput laut telah banyak dipublikasikan pada skala internasional. Azizi, Mansor, Farideh, dan Rosfarizan, ( (2014) melaporkan penggunaan rumput laut coklat Sargassum muticum dalam biosintesis nanopartikel ZnO. Nagarajan \& Kuppusamy (2013) melakukan penelitian sintesis $\mathrm{ZnO}$ dari rumput laut hijau Caulerpa peltata, rumput laut merah Hypnea valencia, dan rumput laut coklat Sargassum myriocystum. Penelitian serupa juga telah dilakukan oleh Purkait, Jagannath, Saikat, dan Mouha (2015); Zelechowska (2014); Ashajyothi (2014); Jegan Ramasubbu, Karunakaran, dan Vasanthkumar (2012).

Nanopartikel ZnO mempunyai aktivitas sebagai semikonduktor, anti bakteri, anti jamur, pembalut luka, penyaring sinar UV, dan agen fotokimia dan katalitik sehingga dapat diaplikasikan pada bidang biologi, biomedis, farmasi, kosmetik dan lain sebagainya (Nagajyothi et al., 2013). ZnO juga memiliki indeks bias, energi ikat, dan konduktivitas termal yang tinggi. Telah dipelajari bahwa nano ZnO menawarkan kinerja yang lebih baik dibandingkan dengan ukuran bulk (Sholehah, 2015). Zink (Zn) merupakan elemen penting untuk kesehatan kita dan nanopartikel $\mathrm{ZnO}$ juga memiliki biokompatibilitas yang baik untuk sel manusia. ZnO juga telah terdaftar sebagai bahan yang aman digunakan oleh US Food and Drug Administration (FDA) (Perwitasari, Aminatun, \& Sumarsih, 2012).

Di Indonesia penelitian mengenai biosintesis nanopartikel $\mathrm{ZnO}$ menggunakan rumput laut belum banyak dilakukan. Dengan kelimpahan rumput laut baik jenis dan jumlahnya serta telah diketahui luasnya manfaat nanopartikel $\mathrm{ZnO}$ pada bidang pangan dan non pangan maka dilakukan penelitian dengan tujuan mendapatkan nanopartikel ZnO dari biosintesis ekstrak rumput laut coklat Sargassum sp. dan Padina sp.

\section{BAHAN DAN METODE}

\section{Bahan}

Bahan utama yang digunakan dalam penelitian ini adalah rumput laut coklat Sargassum sp. dan Padina $\mathrm{sp}$. dari perairan Binuangeun, Banten Selatan. Bahan kimia yang digunakan adalah $\mathrm{Zn}\left(\mathrm{NO}_{3}\right)_{2} \cdot 4 \mathrm{H}_{2} \mathrm{O}$ (Merck), $\mathrm{NaOH}$ (Merck), dan $\mathrm{HCl}$ (Merck). Sedangkan bahan kimia analisis yaitu $\mathrm{ZnO}$ standar (Sigma aldrich), $\mathrm{KBr}$ (Merck), dan etanol (Merck).

Peralatan yang digunakan adalah hammer mill, hot plate (Labinco LD-844), freeze dryer (Christ Beta 2-8 LD plus), type $\mathrm{pH}$ meter-009(I), oven vacuum (Shellab), dan furnace (Thermo Scientific F47920). Peralatan analisis meliputi: instrumentasi Fourier Transform Infrared spectroscopy/FT-IR (Spectrophotometers Perkin Elmer) menganalisis gugus fungsi, Particle Size Analyzer/PSA (Beckman Coulter) mengukur distribusi ukuran partikel, Scanning Electron Microscopy-Energy Dispersive Spectroscopy/ SEM-EDS (Jeol) menganalisis morfologi, dan $X$-ray Diffraction/XRD (Shimadzu XRD-7000 Maxima) menganalisis kristalinitas. 


\section{Metode}

\section{Biosintesis ZnO menggunakan ekstrak Sargassum sp. dan Padina sp.}

Tahap preparasi bahan baku sebagai berikut: Sargassum sp. dan Padina sp. dicuci dengan air laut lalu dibilas dengan air tawar dan dimasukkan ke coolbox yang diberi hancuran es lalu dibawa ke Balai Besar Riset Pengolahan Produk dan Bioteknologi Kelautan dan Perikanan, Jakarta. Sargassum sp. dan Padina sp. dicuci kembali dengan air tawar dan dikering-anginkan selama satu minggu sampai memiliki kadar air sekitar $12-17 \%$ (bk). Sargassum sp. dan Padina sp. kering selanjutnya digiling hingga menjadi tepung untuk memudahkan ekstraksi.

Selanjutnya dilakukan biosintesis nanopartikel $\mathrm{ZnO}$ sebagai berikut:

Tepung Sargassum sp. dan Padina sp. masingmasing sebanyak $1 \mathrm{~g}$ ditambahkan $100 \mathrm{~mL}$ ultrapure (type 1) water dan dipanaskan pada $100^{\circ} \mathrm{C}$ selama 25 menit. Saat ekstraksi digunakan media air deionisasi dengan tujuan menarik senyawa polar yang terkandung dalam Sargassum sp. dan Padina sp. Larutan kemudian disaring dengan kertas saring Whatman No. 41 dan filtrat (ekstrak) ditampung dalam wadah. Sebagian ekstrak dikeringkan menggunakan alat freeze dryer untuk dianalisis gugus fungsi dan ekstrak lainnya disimpan pada tempat penyimpan sampel bersuhu $4{ }^{\circ} \mathrm{C}$ untuk dipreparasi lebih lanjut (Nagarajan \& Kuppusamy, 2013);

Sebanyak $5 \mathrm{~mL}$ ekstrak Sargassum sp. dan Padina sp., masing-masing ditambahkan $95 \mathrm{~mL}$ larutan zink nitrat $10 \mathrm{mM}$ dan diaduk kemudian larutan dipanaskan pada suhu $80^{\circ} \mathrm{C}$ selama 5-10 menit. Tiap-tiap larutan Sargassum sp. dan Padina sp. dibuat sebanyak lima dengan variasi $\mathrm{pH} 8,9,10,11$, dan 12 menggunakan larutan $\mathrm{NaOH}$ 0,1 $\mathrm{M}$ dan diaduk selama 1 jam (Nagarajan \& Kuppusamy, 2013; Sangeetha \& Kumarghru, 2013);

Pemurnian nanopartikel $\mathrm{ZnO}$ dilakukan dengan menyaring filtrat sehingga diperoleh endapan putih. Endapan tersebut kemudian dicuci menggunakan air deionisasi sebanyak tiga kali. Endapan kemudian dikeringkan dengan oven vacuum pada suhu $100^{\circ} \mathrm{C}$ semalam, dan dilanjutkan proses kalsinasi pada suhu $450^{\circ} \mathrm{C}$ selama 4 jam (Nagarajan \& Kuppusamy, 2013; Sangeetha \& Kumarghru, 2013).

\section{Karakteristik seng oksida (ZnO)}

Analisis karakteristik seng oksida $(\mathrm{ZnO})$ meliputi gugus fungsi menggunakan instrumen FT-IR (ASTM, 2010), distribusi ukuran partikel menggunakan instrumen PSA (ASTM, 2007), morfologi permukaan
ZnO menggunakan instrumen SEM-EDS (ASTM, 2012) dan struktur kristal menggunakan instrumen XRD (ASTM, 2013).

Berdasarkan Nurmawati (2007) lebar puncak pada setengah tinggi puncak maksimum (FWHM/full width at half maximum) dapat dihitung dengan menggunakan rumus:

$$
\beta=\frac{1}{2}\left(2 \theta_{2}-2 \theta_{1}\right)
$$

dengan:

B $=$ FWHM (derajat)

$2 \theta_{1}$ dan $2 \theta_{2}=$ jarak antara dua titik yang memiliki nilai setengah dari puncak tertinggi

Nilai FWHM tersebut selanjutnya digunakan untuk menentukan ukuran kristal suatu sampel dengan persamaan Debye Scherrer (Nagarajan \& Kuppusamy, 2013):

$$
D=k \cdot \lambda / \beta \cdot \cos \theta
$$

dengan:

$\mathrm{D}=$ ukuran kristal

$\mathrm{k}=$ konstanta $0,7-1,7$ tergantung bentuk kristal dan indeks miller

$\lambda=$ panjang gelombang

$\beta=$ FWHM (radian)

$\theta=$ sudut difraksi sinar-X pada puncak tertinggi (radian)

\section{HASIL DAN PEMBAHASAN}

\section{Hasil}

Nanopartikel $\mathrm{ZnO}$ yang dihasilkan dari biosintesis ekstrak Sargassum sp. dan Padinasp. dengan variasi pH larutan berwarna putih pucat (pale white) (Gambar 1). Bobot $\mathrm{ZnO}$ dari biosintesis ekstrak Sargassum sp. berkisar antara 1,19-1,79 g/g ekstrak Sargassum sp. dan dari ekstrak Padina sp. berkisar antara 0,01$0,02 \mathrm{~g} / \mathrm{g}$ ekstrak Padina sp. Perbedaan rendemen ini dikarenakan kandungan sulfat polisakarida pada Sargassum sp. dan Padina sp. Jayaraman, Sigamani, Venkatachalam, dan Ramamurthy (2016) menyatakan kadar polisakarida pada Sargassum wightii dan Padina tetratromatica adalah sebesar 15,64 dan $15,16 \%$ sedangkan sulfat polisakarida masing-masing 127 dan $68 \mu \mathrm{g} / \mathrm{mL}$.

Namun nanopartikel $\mathrm{ZnO}$ biosintesis dari ekstrak Padina sp. tidak terbentuk pada $\mathrm{pH} 10$ dan 12. Menurut Sholehah (2015) saat $\mathrm{pH}$ tinggi penambahan larutan $\mathrm{NaOH}$ yang banyak, mengakibatkan terjadinya coverage pertumbuhan nanopartikel $\mathrm{ZnO}$ yang melebihi substratnya. 


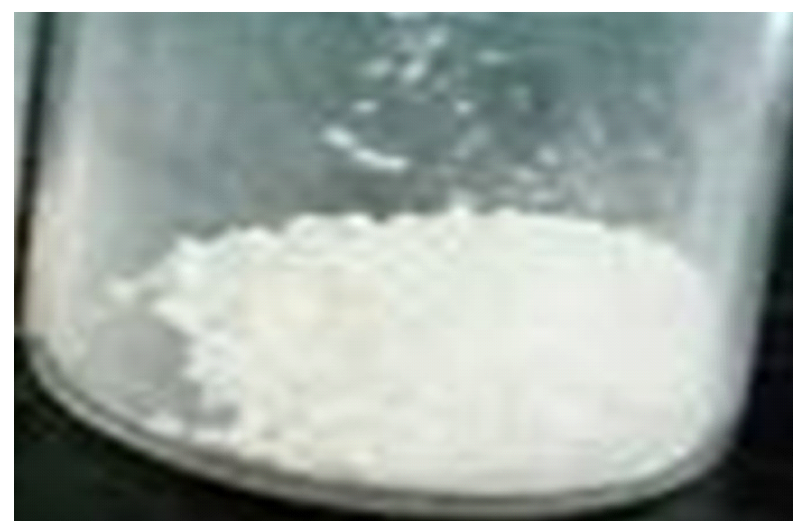

Gambar 1. ZnO yang dihasilkan

Figure 1. ZnO produced

\section{Gugus fungsi ekstrak Sargassum sp., Padina sp., dan ZnO}

Hasil analisis Gugus fungsi ekstrak Sargassum sp., Padina sp., dan ZnO dapat dilihat pada Gambar 2(a-c). Interaksi yang terjadi antara ekstrak Sargassum sp. dan Padina sp. dengan Iarutan prekursor dalam membentuk nanopartikel dapat terlihat dari perubahan puncak spektra FTIR baik berupa pergeseran bilangan gelombang maupun penurunan atau kenaikan intensitas. Hal tersebut dapat digunakan untuk mengetahui gugus-gugus fungsi yang berperan dalam proses reduksi kation $\mathrm{Zn}^{2+}$.

Berdasarkan Gambar 2(a-c), spektra FTIR ekstrak Sargassum sp. dan Padina sp. menunjukkan munculnya puncak-puncak karakteristik gugus fungsional tertentu. Pada ekstrak Sargassum sp. terlihat intensitas melebar pada pita panjang gelombang $3.421,16 \mathrm{~cm}^{-1}$ yang mengindikasikan stretching gugus fungsi $\mathrm{O}-\mathrm{H}$ atau hidroksil. Pita panjang gelombang 2.924,76 $\mathrm{cm}^{-1}$ menunjukkan stretching gugus fungsi $\mathrm{C}-\mathrm{H}$. Pita panjang gelombang $1.739,96 \mathrm{~cm}^{-1}$ menunjukkan stretching $\mathrm{C}=\mathrm{O}$ atau asam karboksilat, 1.646,38 $\mathrm{cm}^{-1}$ vibrasi stretching gugus $(\mathrm{NH}) \mathrm{C}=\mathrm{O}, 1.456,84 \mathrm{~cm}^{-1}$ gugus fungsi $\mathrm{C}-\mathrm{C}$ dari cincin aromatik dengan intensitas sedang sampai lemah. Puncak yang tajam di $1.085,20 \mathrm{~cm}^{-1}$ menunjukkan gugus $\mathrm{C}-\mathrm{O}-\mathrm{C}, \mathrm{C}-\mathrm{O}$ polisakarida. Sedangkan pada ekstrak Padina sp. terlihat intensitas melebar pada pita panjang gelombang $3.428,18 \mathrm{~cm}^{-1}$ yang mengindikasikan stretching gugus fungsi $\mathrm{O}-\mathrm{H}$ atau hidroksil. Pita panjang gelombang $2.925,02 \mathrm{~cm}$ ${ }^{1}$ menunjukkan stretching gugus fungsi $\mathrm{C}-\mathrm{H}, 1.623,31$ $\mathrm{cm}^{-1}$ vibrasi stretching gugus $(\mathrm{NH}) \mathrm{C}=\mathrm{O}, 1.435,95 \mathrm{~cm}^{-}$ ${ }^{1}$ gugus fungsi $\mathrm{C}-\mathrm{C}$ dari cincin aromatik dengan intensitas sedang sampai lemah. Pita panjang gelombang $1.248,52 \mathrm{~cm}^{-1}$ menunjukkan simetris dari vibrasi stretching gugus sulfat ester. Pita panjang gelombang 837,31 menunjukkan gugus sulfat polisakarida, spektra dari ekstrak Sargassum sp. dan Padina sp. yang diperoleh dari hasil penelitian ini sesuai dengan Azizi et al. (2014), dan Nagarajan \& Kuppusamy (2013).

Spektra FTIR ekstrak Sargassum sp. dan Padina sp. tampak ada perbedaan intensitas maupun lebar puncak setelah ekstrak berinteraksi dengan larutan prekursor zink nitrat. Pada ekstrak Sargassum sp. perubahan terjadi di pita panjang gelombang 3.421,16; 1.646,38; dan 1.456,84. Sedangkan pada ekstrak Padina sp. di 3.428,18; 1.623,31; dan 1.435,95. Menurut Pongpiachan (2014); Sakthivel, Deivasigamani, Rajasekar, Kumaran, dan Alagappan (2015) intensitas pita panjang gelombang 3.200-3.600 $\mathrm{cm}^{-1}$ mengalami perubahan setelah proses reduksi kation $\mathrm{Zn}^{2+}$ yang menunjukkan adanya keterlibatan gugus fungsi $\mathrm{O}-\mathrm{H}$ dalam proses reduksi. Pergeseran pita panjang gelombang 1630-1.647,93 $\mathrm{cm}^{-1}$ menunjukkan getaran peregangan (stretching) gugus fungsional $(\mathrm{NH}) \mathrm{C}=\mathrm{O}$ yang merupakan karakteristik protein (Azizi et al., 2014). Hal tersebut menunjukkan gugus fungsi $(\mathrm{NH}) \mathrm{C}=\mathrm{O}$ dengan bentuk peptida siklik terlibat dalam menstabilkan nanopartikel (Azizi et al., 2014). Peletiri Matur, Ihongbe, dan Okoye (2012) juga melaporkan bahwa protein terlibat dalam proses reduksi $\mathrm{Zn}^{2+}$ menjadi $\mathrm{ZnO}{ }^{\circ}$ dengan berfungsi sebagai capping agent dalam sintesis nanopartikel $\mathrm{ZnO}$. Munculnya bilangan gelombang $1.345-1.384 \mathrm{~cm}^{-1}$ pada nanopartikel $\mathrm{ZnO}$ dari ekstrak Sargassum sp. dan Padina sp. menunjukkan banyak gugus fungsi $\mathrm{N}-\mathrm{O}$ yang diduga berasal dari prekursor $\mathrm{ZnNO}_{3}$ (Pongpiachan, 2014). Gambaran detail spektra FTIR ekstrak Sargassum sp., Padina sp., dan $\mathrm{ZnO}$ yang dihasilkan dari biosintesis pada variasi $\mathrm{pH}$ dapat dilihat pada Tabel $1 \mathrm{a}$ dan $1 \mathrm{~b}$.

Perubahan-perubahan intensitas dan lebar puncak yang terjadi menunjukkan keterlibatan kelompok sulfat dan hidroksil pada pembentukan nanopartikel. Ikatanikatan di atas umumnya terjadi pada polisakarida yang 


\section{Ekstrak Sargassum $s p$.}

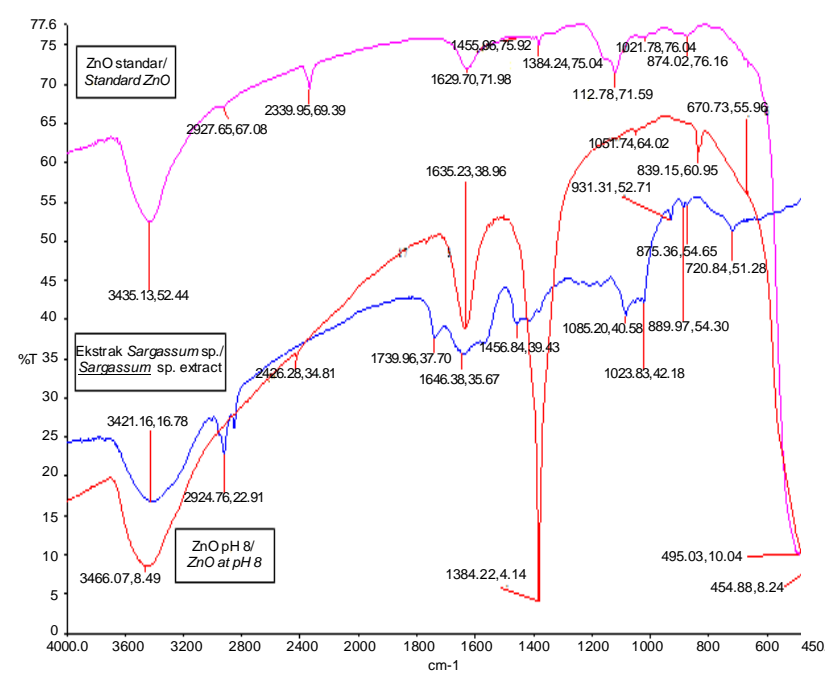

(a) $\mathrm{pH} 8$

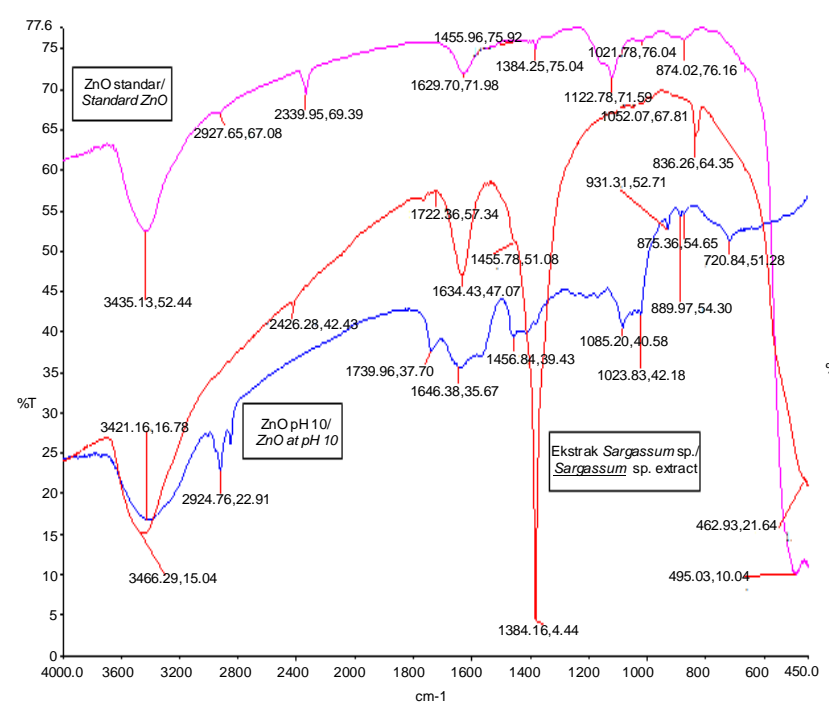

(c) $\mathrm{pH} 1 \mathrm{U}$

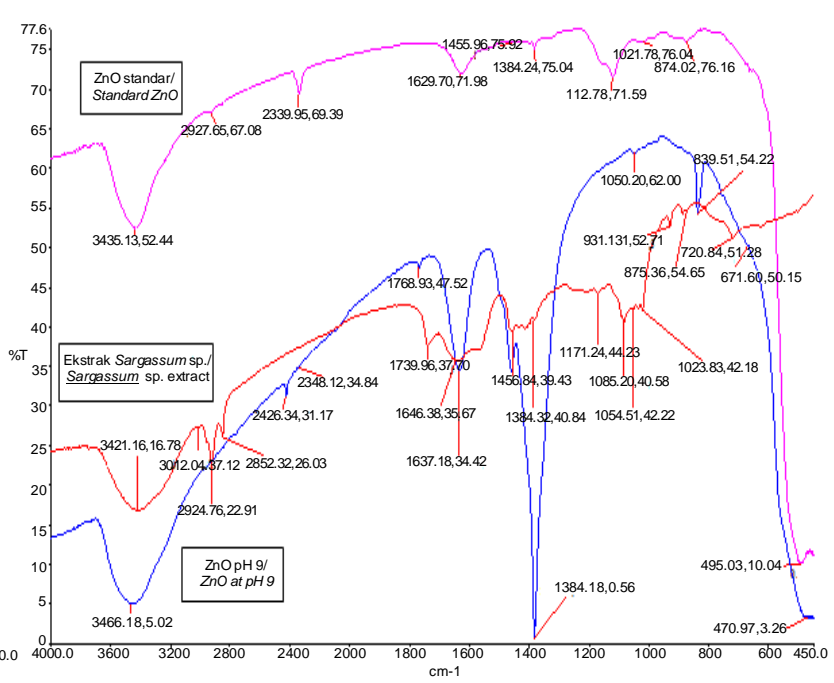

(b) $\mathrm{pH} 9$

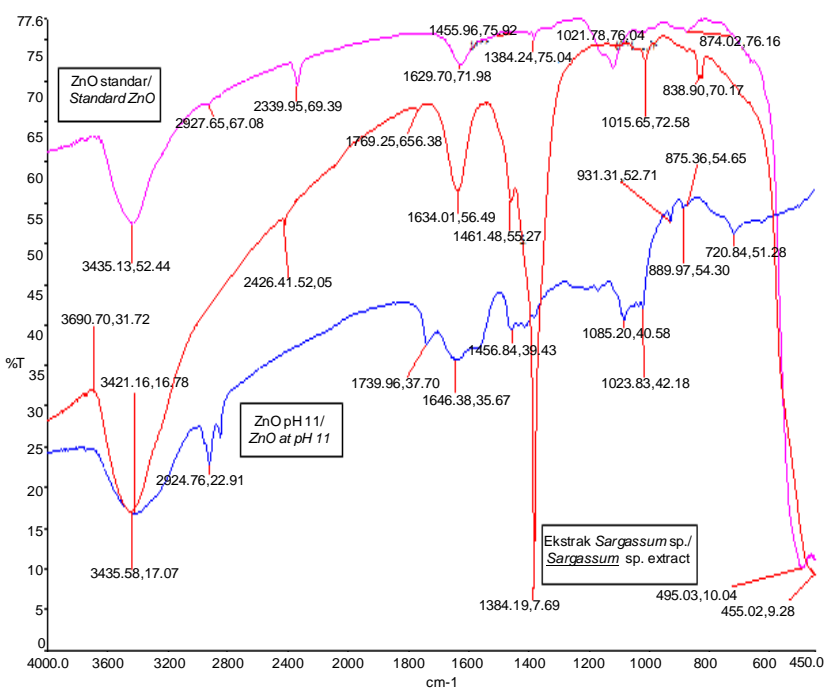

(d) $\mathrm{pH} 11$

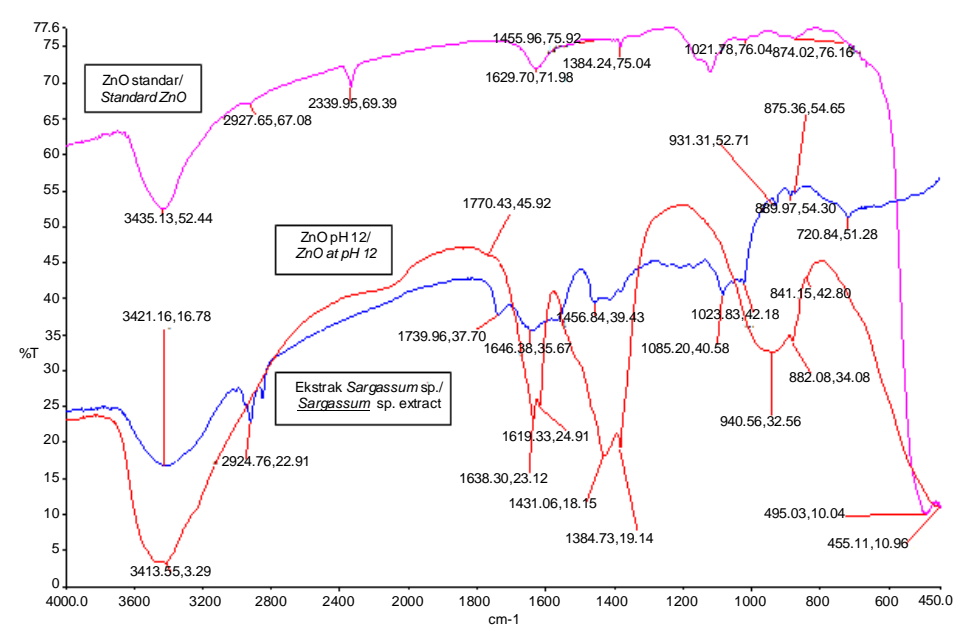

(e) $\mathrm{pH} 12$

Gambar 2a. Gugus fungsi ekstrak Sargassum sp. (a-e) Figure 2a. Functional groups of Sargassum sp. extract (a-e) 
Ekstrak Padina sp./Padina sp. extract

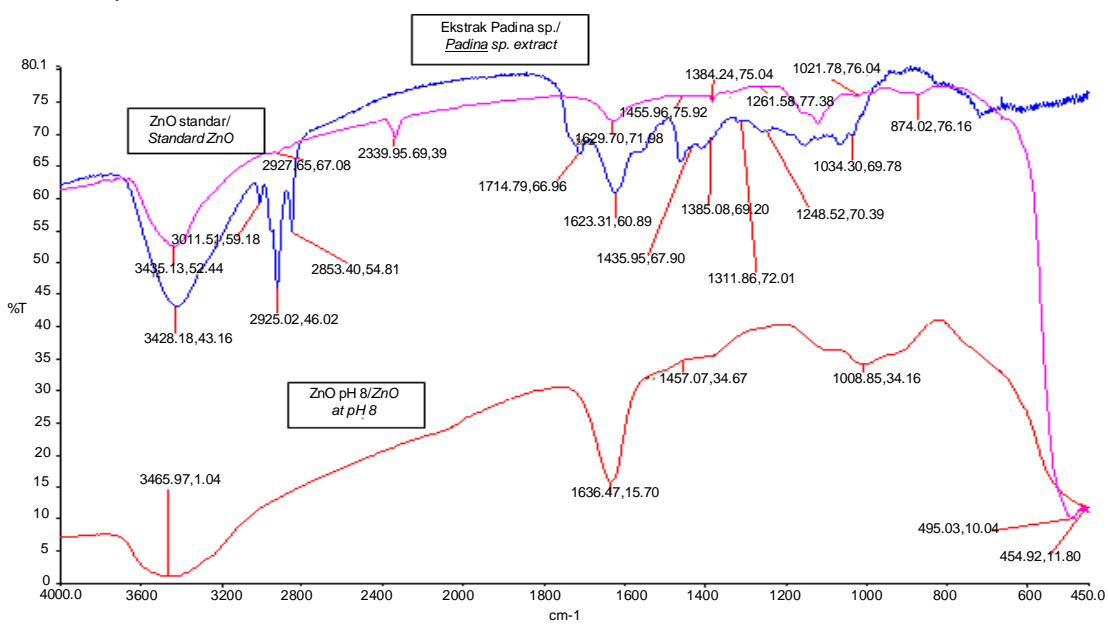

(a) $\mathrm{pH} 8$

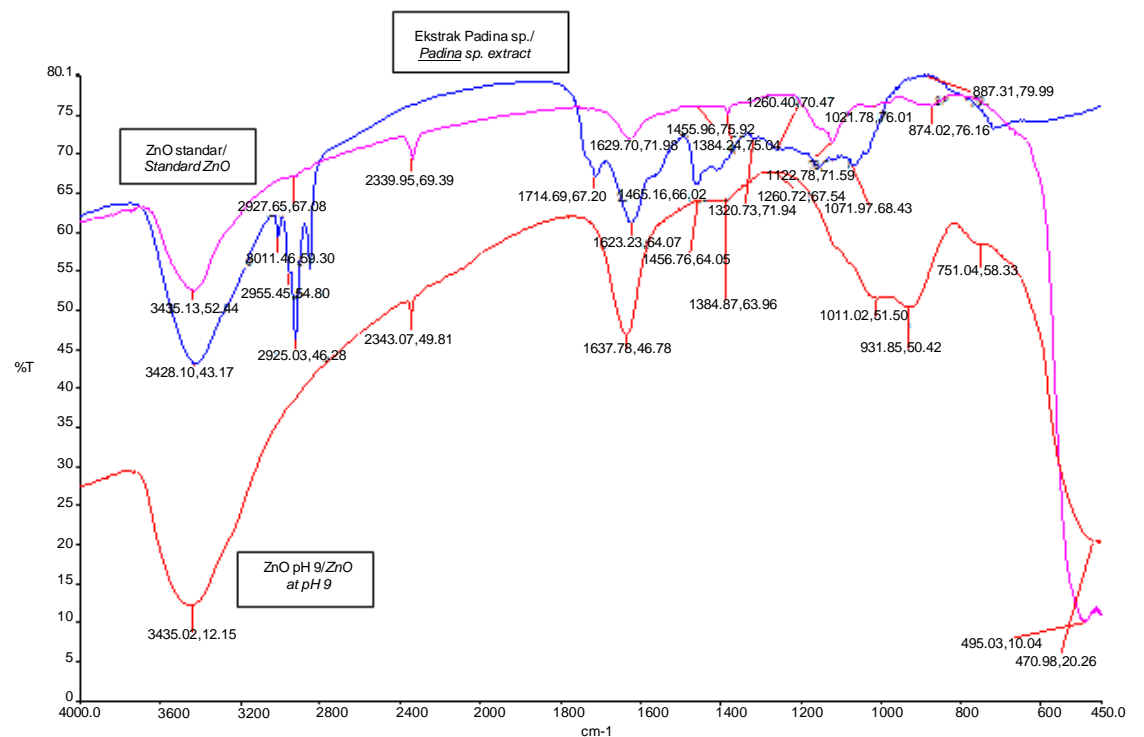

(b) $\mathrm{pH} 9$

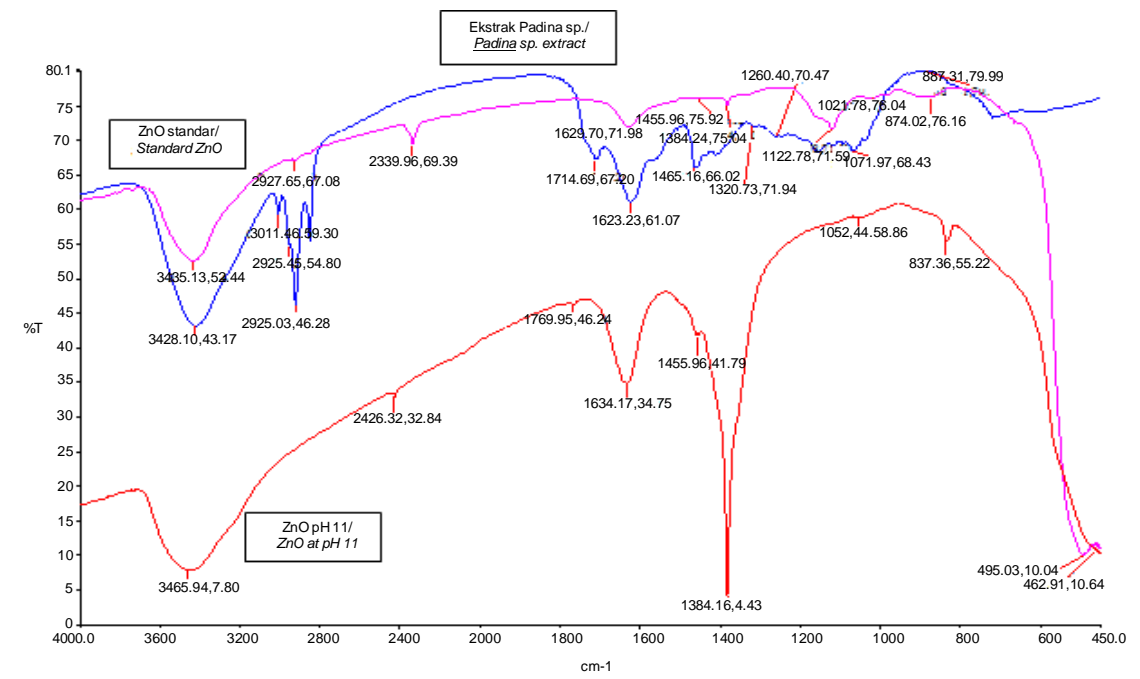

(c) $\mathrm{pH} 11$

Ket/Note: ZnO tidak terbentuk pada pH 10 dan 12/ZnO was not formed at pH 10 and 12

Gambar 2b. Gugus fungsi ekstrak Padina sp. (a-c)

Figure 2b. Functional groups of Padina sp. extract (a-c) 


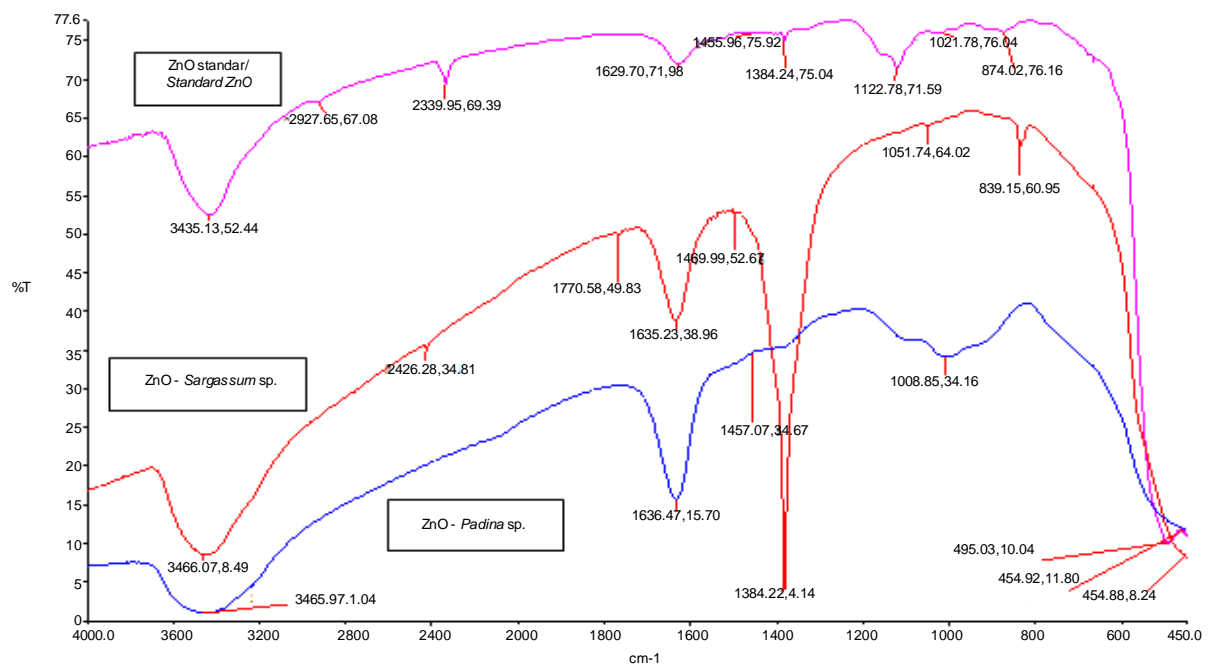

(a) $\mathrm{pH} 8$

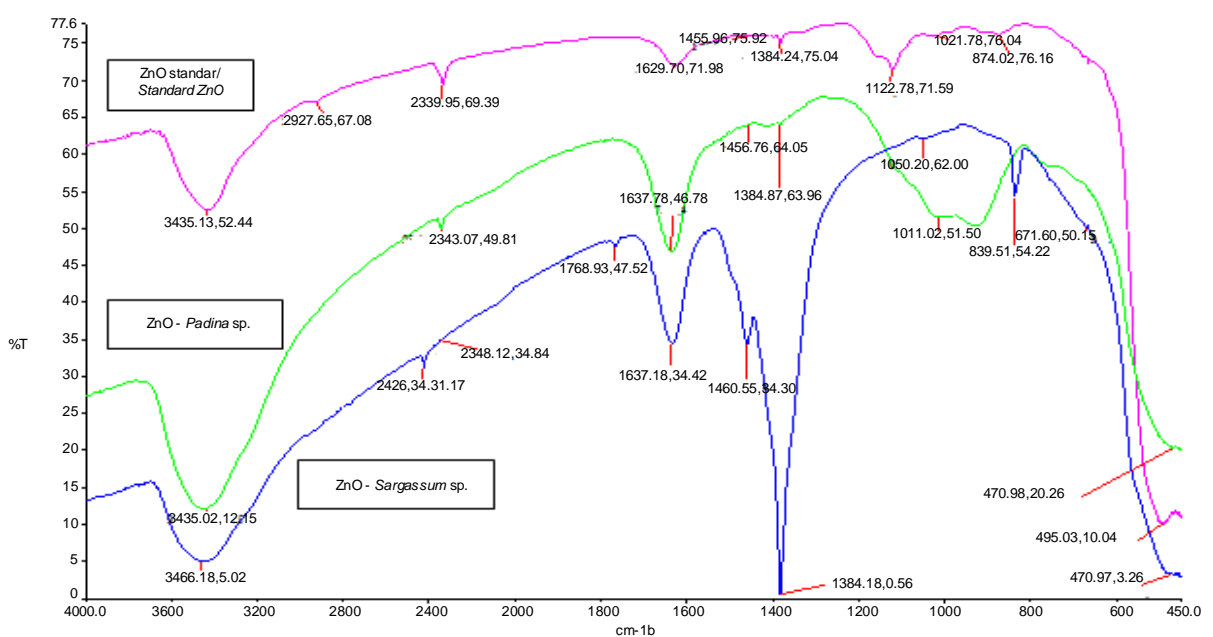

(b) $\mathrm{pH} 9$

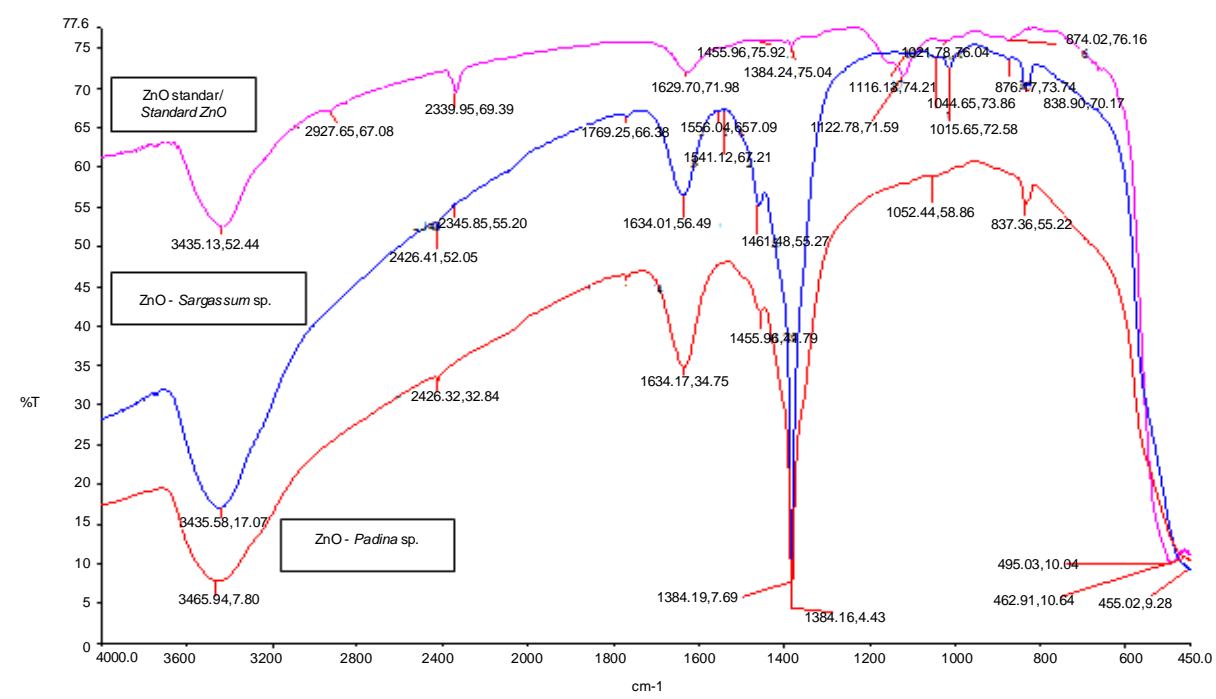

(c) $\mathrm{pH} 11$

Gambar 2c. Gugus fungsi ZnO - Sargassum sp. dan ZnO - Padina sp. yang dihasilkan pada variasi pH yang sama dengan $\mathrm{ZnO}$ standar

Figure 2c. Functional groups of $\mathrm{ZnO}$ - Sargassum sp. and $\mathrm{ZnO}$ - Padina sp. that produced at the same $\mathrm{pH}$ with $\mathrm{ZnO}$ standard 


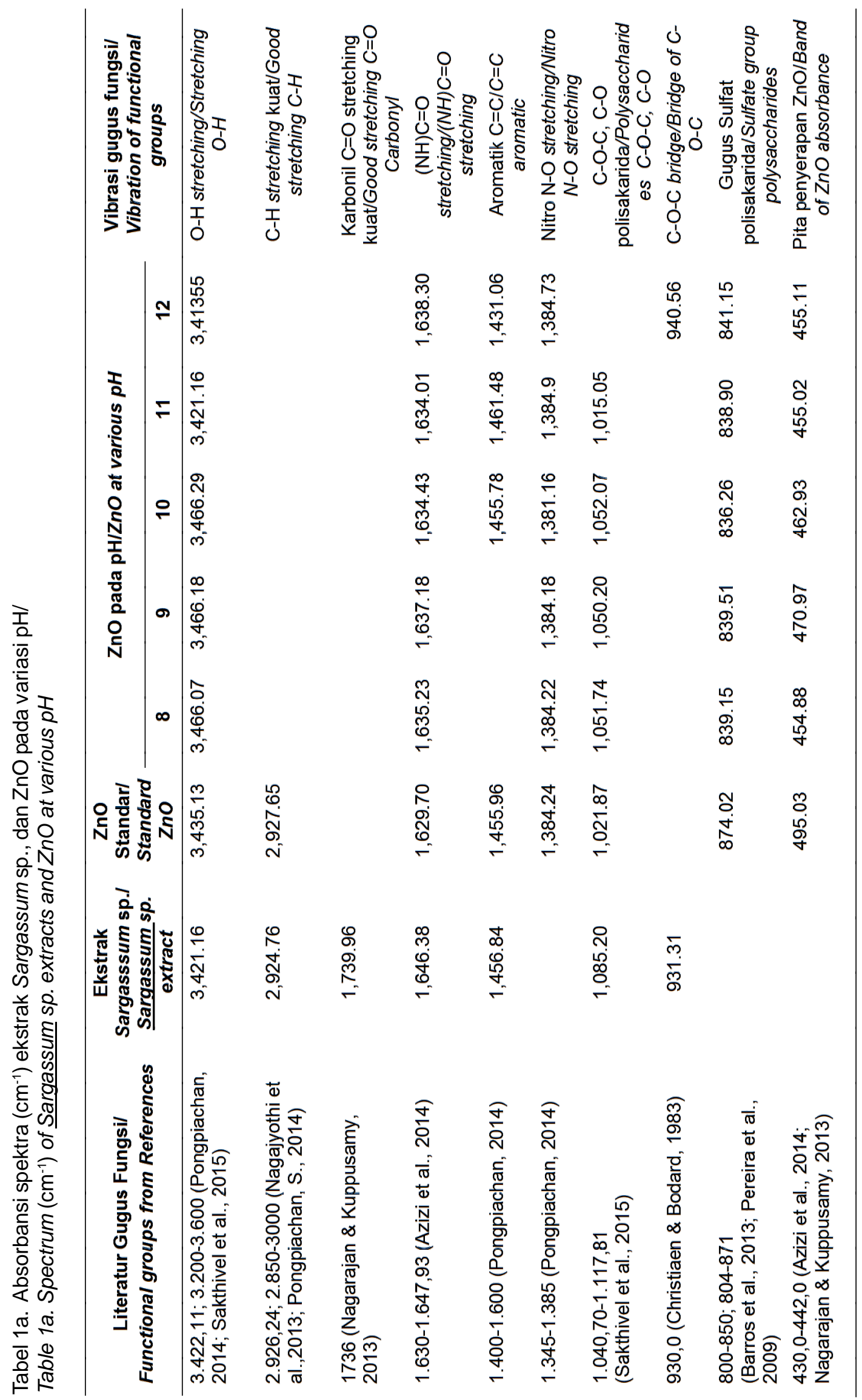




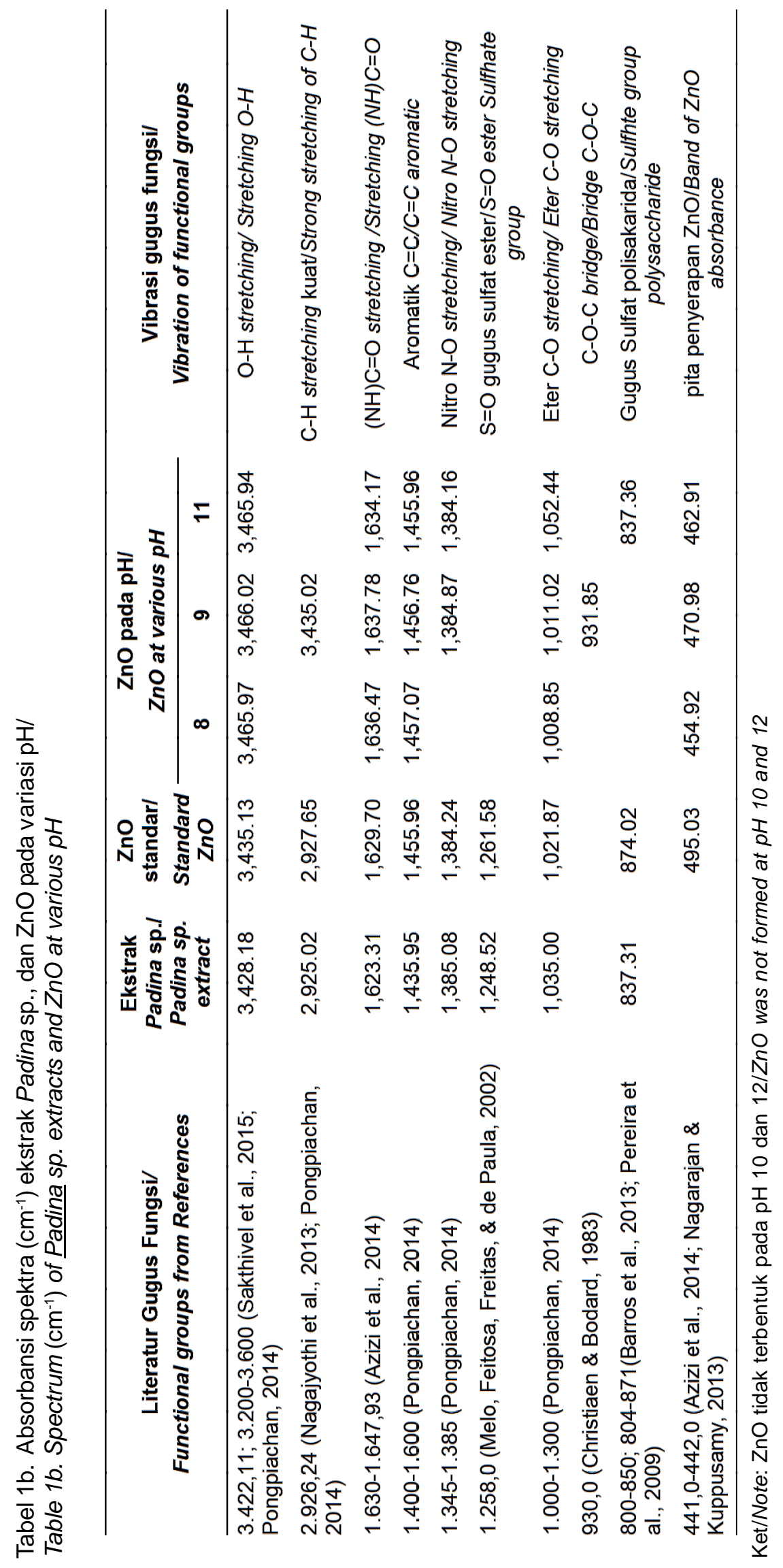


menunjukkan keikutsertaan polisakarida sulfat dalam sintesis nano partikel ZnO (Azizi et al., 2014). Ekstrak Sargassum sp. dan Padina sp memiliki gugus fungsi hidroksi dan karbonil. Menurut Tiwari dan Declan (2015) gugus fungsi ini berperan sebagai ligan yang mendonorkan pasangan elektron bebas ke orbital $\mathrm{Zn}^{2+}$ kemudian $\mathrm{Zn}^{2+}$ dan gugus polar tersebut membentuk senyawa kompleks dalam template yang berukuran nano. Senyawa kompleks terbentuk melalui ikatan kovalen koordinasi antara ligan dengan logam. Ligan akan menyumbangkan pasangan elektron bebas ke ion logam yang menyediakan orbital kosong. Ion logam bertindak sebagai asam Lewis sedangkan ligan sebagai basa Lewis. Senyawa kompleks yang terbentuk memiliki efek kelat yang lebih stabil. Nanopartikel ZnO terbentuk setelah proses kalsinasi. Namun mekanisme dalam pembentukan $\mathrm{ZnO}$ nanopartikel melalui metode green synthesis belum dapat dikonfirmasikan secara pasti.

Azizi et al. (2014) menemukan bahwa bahan aktif dalam S. muticum seperti amino, sulfat, karboksil, dan gugus hidroksil berperan dalam keseluruhan proses biosintesis yang terjadi. Nagarajan \& Kuppusamy (2013) menyatakan bahwa fitokimia terlarut dalam S. myriocystum seperti asam alginat, asam asorbat, protein, karbohidrat, flavanoid, tanin, manitol, dan lemak berperan sebagai agen pereduksi dan penstabil dalam pembentukan nanopartikel $\mathrm{ZnO}$. Visinescu, Greta, Alina, \& Oana (2012) menyatakan sifat unik dari polisakarida jenis alginat adalah kemampuannya mengikat kation divalent atau trivalen.
Kemampuan ini sering disebut sebagai model "eggbox". Kation terikat pada sisi negatif molekul alginat yaitu gugus karboksil berikatan elektrostatik dengan logam dan membentuk pola cross-linking. Alginat diketahui memiliki gugus karboksil dalam jumlah yang berlimpah sehingga dapat membentuk interaksi koordinasi dengan ion logam dan berperan sebagai tempat terjadinya nukleasi dalam pembentukan nanopartikel.

Spektrum FTIR untuk ZnO dari hasil peneltian sebelumnya adalah $441 \mathrm{~cm}^{-1}$ (Azizi et al., 2014), 442 $\mathrm{cm}^{-1}$ (Nagarajan \& Kuppusamy, 2013), 486,06 cm-1 (Ehsan \& Sajjad, 2017), $528 \mathrm{~cm}^{-1}$ (Selvarajan \& Mohanasrinivasan, 2013), dan 620,93 $\mathrm{cm}^{-1}$ (Kumar \& Rani, 2013). Hasil analisis gugus fungsi menunjukkan pita penyerapan ZnO biosintesis ekstrak Sargassum sp. dan Padina sp. yang mendekati ZnO standar tidak ditemukan pada seluruh sampel namun pita penyerapan $\mathrm{ZnO}$ sudah berada pada kisaran nilai spketrum ZnO dari penelitian yang sudah dilakukan. Langkah selanjutnya untuk memastikan ZnO NPs secara kualitatif dilakukan analisis pola difraksi menggunakan instrumen XRD.

\section{Distribusi ukuran partikel ZnO}

Analisa distribusi ukuran partikel dilakukan menggunakan pelarut etanol. Hasil ukuran partikel ZnO dapat dilihat pada Gambar 3. Ukuran partikel ZnO dari biosintesis ekstrak Sargassum sp. dengan prekursor $\mathrm{ZnNO}_{3}$ pada variasi $\mathrm{pH}$ larutan 8-12 rata-rata berkisar antara 1.396,33-3.090,50 nm. Distribusi ukuran sudah

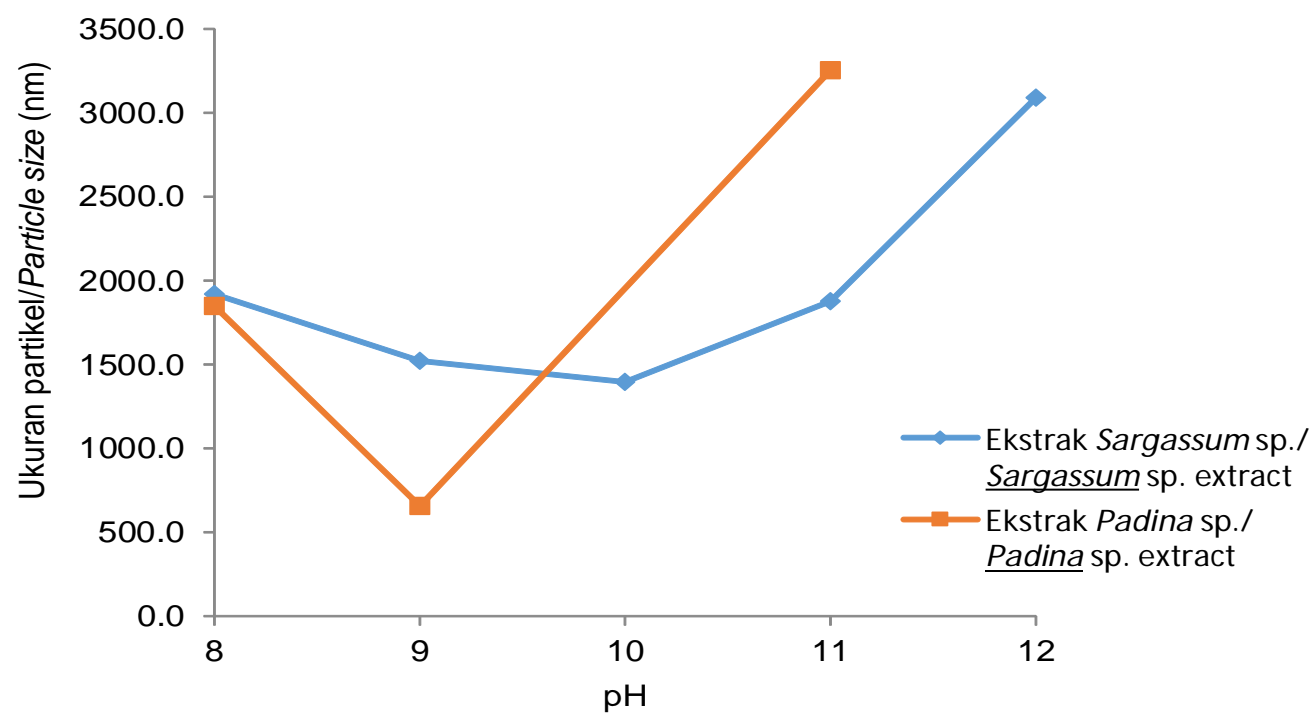

Ket/Note : ZnO - ekstrak Padina sp. tidak terbentuk pada pH 10 dan 12. Pengukuran dilakukan dengan 10x ulangan/ $\mathrm{ZnO}$ - extract Padina sp. was not formed at pH 10 and 12. Measurement was conducted in 10 replicates

Gambar 3. Ukuran partikel ZnO dari biosintesis ekstrak Sargassum sp. dan Padina sp. dengan variasi pH Figure 3. Particle size of ZnO from biosynthesized Sargassum sp. and Padina sp. extracts at various pH 
Nanopartikel Seng Oksida $(\mathrm{ZnO})$ dari Biosintesis Ekstrak Rumput Laut Coklat............(Rodiah Nurbaya Sari et al)

homogen namun belum memenuhi besaran ukuran nano (1-100 nm). Rata-rata ukuran partikel $\mathrm{ZnO}$ terkecil pada variasi $\mathrm{pH} 10$. Sedangkan ukuran partikel produk $\mathrm{ZnO}$ dari biosintesis ekstrak Padina sp. ratarata berkisar antara 655,91-3.253,06 nm. Distribusi ukuran sudah homogen namun belum memenuhi besaran ukuran nano. Rata-rata ukuran partikel $\mathrm{ZnO}$ terkecil pada variasi $\mathrm{pH} 9$.

Berdasarkan hasil ukuran partikel yang diperoleh diketahui sistem koloid nanopartikel $\mathrm{ZnO}$ cenderung kurang stabil sehingga ukuran rata-rata nanopartikel $\mathrm{ZnO}$ dengan konsentrasi ekstrak $5 \%$ (v/v) dan variasi $\mathrm{pH}$ yang terbentuk belum berukuran nano. Hal ini diduga karena efektivitas Sargassum sp. dan Padina sp. yang berperan sebagai agen penstabil masih rendah. Menurut Dumur et al. (2011) diperlukan penstabil kuat untuk dapat mencegah agregasi yang dapat membatasi pertumbuhan kluster sehingga kluster $\mathrm{Zn}^{\circ}$ yang terbentuk tidak tumbuh menjadi ukuran lebih besar dan tetap berukuran nano.

Ekstrak Sargassum sp. dan Padina sp. berperan juga sebagai agen pereduksi untuk memerangkap prekursor zink nitrat. Setelah kation $\mathrm{Zn}^{2+}$ tereduksi menjadi logam yang bermuatan nol maka senyawa ekstrak berada di sekeliling permukaan nanopartikel yang terbentuk. Ketika logam zink masih bermuatan positif atau belum tereduksi, ukuran partikelnya berada dalam skala angstrom dan senyawa ekstrak sebagai zat pemerangkap ukurannya lebih dominan dibandingkan kation tersebut sehingga ukuran partikel yang dihasilkan mengikuti ukuran senyawa ekstrak. Foliatini, Yulizar, dan Hafizah (2015) menyatakan ukuran $\mathrm{ZnO}$ yang dihasilkan sangat bergantung pada ukuran template yang mengelilingi permukaan nanopartikel.

Seiring dengan berjalannya waktu reaksi reduksi terjadi semakin banyak sehingga antar partikel mengalami penggabungan dan menghasilkan ukuran partikel yang semakin besar. Kecenderungan partikel untuk beragregasi disebabkan oleh efek gerak brown atau gerakan terus menerus partikel yang terjadi dalam larutan. Kecenderungan ini menyebabkan diameter partikel tidak seragam. Agregasi nanopartikel terjadi melalui dua tahapan yaitu tahap pertama partikel saling mendekat dan saling bertumbuk satu sama lain dan tahap kedua partikel yang bertumbuk saling melekat satu sama lain (Masakke, Sulfikar, \& Muhaedah, 2015).

Ukuran partikel terkecil ZnO dari biosintesis ekstrak Sargassum sp. dan Padina sp. yang dihasilkan dari penelitian ini terdapat pada perlakuan $\mathrm{pH}$ larutan 10 dan 9 meskipun ukuran tersebut tidak memenuhi kategori ukuran nano. Nagarajan \& Kuppusamy (2013) menyatakan pada $\mathrm{pH}$ rendah agregasi nanopartikel $\mathrm{ZnO}$ mengarah pada pembentukan nanopartikel yang lebih besar di sekitaran nukleasi. Hasil penelitian Nagarajan \& Kuppusamy (2013) dalam sintesis ZnO menggunakan ekstrak Sargassum myriocystum 5\% ( $\mathrm{v} / \mathrm{v})$ dan prekursor zink nitrat $1 \mathrm{mM}$ menghasilkan ukuran partikel $36 \mathrm{~nm}$ pada $\mathrm{pH}$ 8. Menurut Mata et al. (2009) $\mathrm{pH}$ yang lebih tinggi menyebabkan kemampuan reduksi juga menjadi lebih tinggi. Sebagaimana dilaporkan proses reduksi terjadi pada dua tahap dengan pH optimum yaitu 4-9 dan serapan maksimum terjadi pada $\mathrm{pH}$ 7. Selama biosintesis berlangsung, proses dikontrol oleh $\mathrm{pH}$ larutan. $\mathrm{pH}$ mempengaruhi ukuran partikel yang dihasilkan. Kemampuan berbagai gugus fungsi untuk mereduksi berkurang dengan adanya konsentrasi $\mathrm{H}^{+}$yang tinggi pada kondisi $\mathrm{pH}$ rendah. Namun saat $\mathrm{pH}$ ditingkatkan kemampuan berbagai gugus fungsi sebagai pereduksi meningkat sehingga meningkatkan kestabilan serta mencegah terjadinya aglomerasi seiring dengan meningkatnya ion $\mathrm{OH}^{-}$(Sharma, Sharma, \& Sharma, 2015). Saat suplai $\mathrm{NaOH}$ yang lebih banyak ( $\mathrm{pH}$ tinggi), sebagai agen pereaksi pembentuk $\mathrm{ZnO}$ dari ion prekursor $\mathrm{Zn}^{2+}$ juga memberikan efek terhadap coverage pertumbuhan nanopartikel $\mathrm{ZnO}$ di atas substrat (Sholehah, 2015).

Dengan bertambahnya ion $\mathrm{OH}^{-}, \mathrm{Zn}^{2+}$ akan membentuk $\mathrm{Zn}(\mathrm{OH})_{2}$ dan $\mathrm{ZnO}_{2}{ }^{2-}$ yang nantinya berubah menjadi $\mathrm{ZnO}$ seiring dengan adanya pemanasan. Selanjutnya presipitat/nuklei $\mathrm{ZnO}$ yang terdapat dalam larutan tumbuh menjadi kristal dengan ukuran lebih besar melalui proses kristalisasi. Seiring dengan berjalannya waktu, molekul $\mathrm{Zn}^{2+}$ bereaksi dan terkonsumsi sampai habis dan menghasilkan populasi nuklei ZnO lebih banyak (Wang et al., 2006). Di sisi lain, kehadiran suplai nuklei yang bertambah banyak tersebut menghasilkan pertumbuhan partikel pada sumbu vertikal hingga mengakibatkan diameter individual masing-masing partikel menjadi lebih kecil. $\mathrm{NaOH}$ memberikan kontribusi lebih besar saat proses hidrolisis (Sholehah, 2015). Menurut Vernardou et al. (2006), efek morfologi $\mathrm{ZnO}$ yang tumbuh di atas substrat dalam sistem aqueous chemical growth sangat dipengaruhi oleh $\mathrm{pH}$ larutan. Kenaikan $\mathrm{pH}$ larutan dapat mengubah struktur. $\mathrm{Pada} \mathrm{pH}$ yang lebih tinggi, $\mathrm{ZnO}$ akan membentuk struktur nanoflower dan pada $\mathrm{pH}$ lebih rendah, cenderung membentuk nanorods. Namun Bian, Mudunkotuwa, Rupasinghe, dan Grassian (2011) menyatakan ketidaklarutan ZnO dalam larutan aqueous diketahui terjadi pada kisaran $\mathrm{pH}$ yang luas. Selain $\mathrm{pH}$ larutan reaksi, pembentukan nanopartikel dipengaruhi oleh beberapa faktor lainnya yaitu konsentrasi rumput laut, konsentrasi garam logam (prekursor), waktu reaksi, dan suhu. Menurut Fawcett, Verduin, Shah, Sharma, \& Poinern (2017) selain $\mathrm{pH}$, faktor lain yang mempengaruhi ukuran partikel $\mathrm{ZnO}$ adalah suhu reaksi saat proses 
biosintesis berlangsung. Pengontrolan terhadap faktorfaktor tersebut menentukan kualitas, ukuran, dan bentuk nanopartikel hasil biosintesis (Shah, Fawcett, Sharma, Tripathy, \& Poinern, 2015). Ukuran partikel merupakan karakteristik paling penting dalam sistem nanopartikel karena menentukan distribusi in vivo, toksisitas, dan kemampuan target. Selain itu ukuran partikel mempengaruhi drug loading, drug realase, dan kestabilan sistem nanopartikel (Mohanraj \& Cheng, 2007).

\section{Morfologi permukaan ZnO}

Pengamatan SEM telah dilakukan namun karena keterbatasan deteksi yang dimiliki oleh alat pencitraan, sampel $\mathrm{ZnO}$ hanya bisa dilakukan pada perbesaran sampai 3.000x dan foto yang dihasilkan juga tidak maksimal (Gambar 4). Dari Gambar tersebut keseluruhan sampel dapat dikatakan berbentuk spherical namun tidak seragam dan celah antar partikel tidak dapat terlihat jelas. Ketidakseragaman bentuk tersebut diduga terjadi karena adanya aglomerasi di antara partikel-partikel ZnO (Gunalan, Sivaraj, \& Rajendran, 2011). Aglomerasi tersebut dikarenakan pengaruh polaritas, daya elektrostatik $\mathrm{ZnO}$, dan energi yang besar di permukaan sampel yang biasa terjadi ketika proses sintesis berlangsung ( Azizi et al. 2014; Elumalai \& Velmurugan, 2015; Zhang et al., 2002). Aglomerasi juga dapat terjadi karena masih banyak senyawa-senyawa kimia yang terkandung dalam ekstrak Sargassum sp. dan Padina sp. yang ikut berperan sebagai pemerangkap (template) untuk prekursor zink nitrat. Faktor lain yang juga mempengaruhi morfologi $\mathrm{ZnO}$ yang terbentuk adalah suhu reaksi saat biosintesis berlangsung (Fawcett et al., 2017).

Analisis selanjutnya dilakukan dengan instrumen EDS. Hasil analisis ZnO dari biosintesis ekstrak Sargassum sp. dan Padina sp. dibandingkan dengan $\mathrm{ZnO}$ standar. Hasil analisis dapat dilihat pada Tabel 2. Tabel tersebut menunjukkan nilai persen massa dan persen atom $\mathrm{Zn}$ dan $\mathrm{O}$ yang mendekati standar $\mathrm{ZnO}$ adalah $\mathrm{ZnO}$ dari biosintesis ekstrak Sargassum

(a) ZnO - ekstrak Sargassum sp./ZnO - Sargassum sp. extract
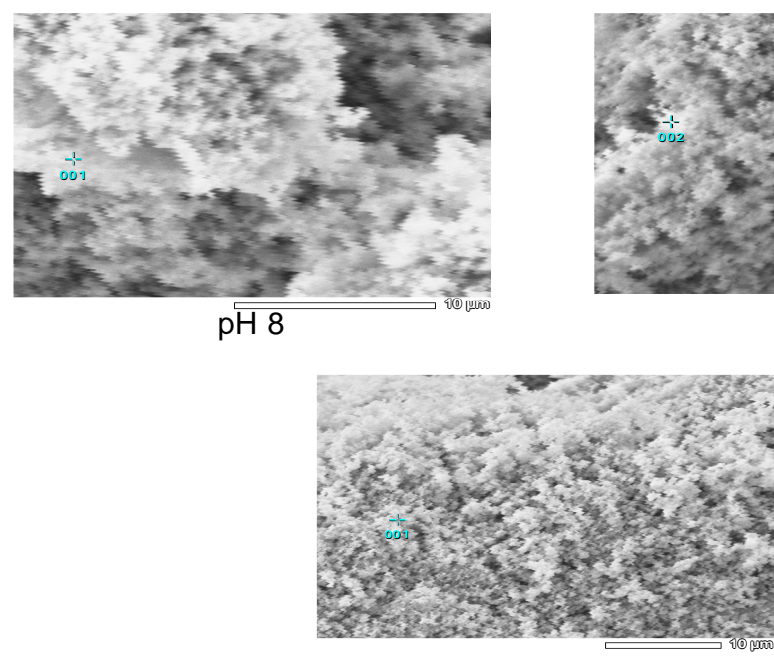

$\mathrm{pH} 11$

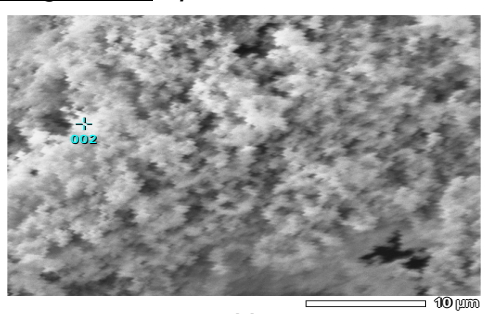

$\mathrm{pH} 9$

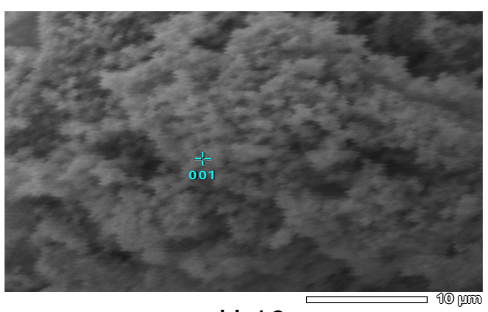

$\mathrm{pH} 10$

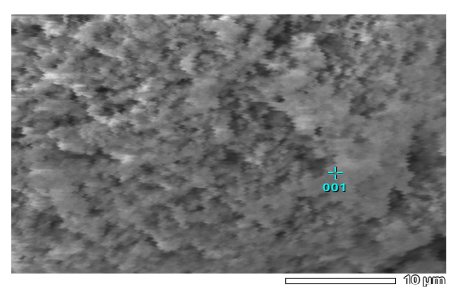

$\mathrm{pH} 12$

(b) ZnO - ekstrak Padina sp./ZnO - Padina sp. extract

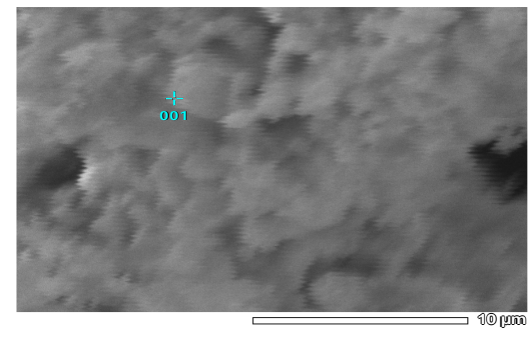

$\mathrm{pH} 8$

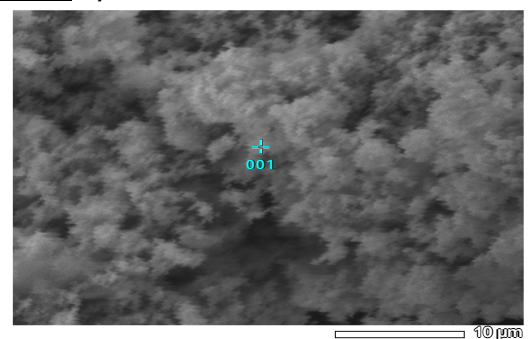

$\mathrm{pH} 9$

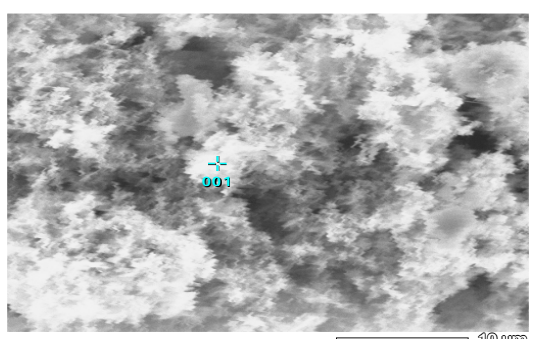

$\mathrm{pH} 11$

Gambar 4. Hasil analisis SEM perbesaran 3.000x untuk ZnO dari biosintesis ekstrak Sargassum sp. (a) dan Padina sp. (b) dengan variasi $\mathrm{pH}$

Figure 4. SEM analysis of ZnO $3000 x$ scale of biosynthesized (a) Sargassum sp. and (b) Padina sp. extracts at various $\mathrm{pH}$ 
Tabel 2. Hasil analisis EDS standar $\mathrm{ZnO}$ dan biosintesis $\mathrm{ZnO}$ Table 2. EDS Analysis of $\mathrm{ZnO}$ standard and $\mathrm{ZnO}$ biosynthesized

\begin{tabular}{|c|c|c|c|c|c|c|c|}
\hline \multirow{5}{*}{$\begin{array}{l}\text { Perlakuan/ } \\
\text { Treatment }\end{array}$} & \multicolumn{7}{|c|}{ Sampel/Sample } \\
\hline & \multicolumn{2}{|c|}{$\begin{array}{l}\text { Standar ZnO / } \\
\text { ZnO Standard }\end{array}$} & \multirow{2}{*}{\multicolumn{2}{|c|}{$\begin{array}{l}\text { Ekstrak Sargassum sp./ } \\
\text { Sargassum sp. Extract } \\
\text { Elemen/Element }\end{array}$}} & \multicolumn{3}{|c|}{$\begin{array}{c}\text { Ekstrak Padina sp./ } \\
\text { Padina sp. Extract }\end{array}$} \\
\hline & & & & & & & \\
\hline & $\%$ Massa & $\%$ Atom & $\%$ Massa & $\%$ Atom & $\%$ & Massa & $\%$ Atom \\
\hline & $\begin{array}{lr}\text { Zn } & 91.09 \\
0 & 8.91\end{array}$ & $\begin{array}{l}\text { Zn } 71.46 \\
\text { O } 28.54\end{array}$ & & & & & \\
\hline \multirow[t]{2}{*}{$\mathrm{pH} 8$} & & & Zn 60.07 & Zn 26.91 & $\mathrm{Zn}$ & 82.68 & Zn 53.88 \\
\hline & & & O 39.93 & O 73.09 & $\mathrm{O}$ & 17.32 & O 46.12 \\
\hline \multirow[t]{2}{*}{$\mathrm{pH} 9$} & & & Zn 79.15 & Zn 48.16 & & 94.67 & $\mathrm{Zn} 81.30$ \\
\hline & & & O 20.85 & O 51.84 & $\mathrm{O}$ & 5.33 & O 18.70 \\
\hline \multirow[t]{2}{*}{$\mathrm{pH} 10$} & & & Zn 95.98 & $\mathrm{Zn} 85.40$ & - & & - \\
\hline & & & O 4.02 & O 14.60 & & & \\
\hline \multirow[t]{2}{*}{$\mathrm{pH} 11$} & & & Zn 63.15 & Zn 29.55 & $\mathrm{Zn}$ & 53.00 & Zn 21.63 \\
\hline & & & O 36.85 & O 70.45 & O & 47.00 & O 78.37 \\
\hline \multirow[t]{2}{*}{$\mathrm{pH} 12$} & & & Zn 57.06 & $\mathrm{Zn} 24.54$ & - & & - \\
\hline & & & O 42.94 & O 75.46 & & & \\
\hline
\end{tabular}

sp. pada pH larutan 10 dan Padina sp. pH 9. Rosyidah, Purwaningsih, dan Darminto (2017) melakukan penelitian sintesis $\mathrm{ZnO}$ dengan metode kopresipitasi dan diperoleh hasil yaitu pembentukan nanopartikel $\mathrm{ZnO}$ untuk variasi $\mathrm{pH}$ dengan ukuran partikel terkecil $32 \mathrm{~nm}$ pada $\mathrm{pH}$ 10. Nagarajan dan Kuppusamy (2013) mensintesis $\mathrm{ZnO}$ dengan ekstrak Sargassum myriocystum $5 \%(\mathrm{v} / \mathrm{v})$ dan prekursor zink nitrat $1 \mathrm{mM}$ menghasilkan ukuran partikel $36 \mathrm{~nm}$ pada $\mathrm{pH} 8$. Kondisi $\mathrm{pH}$ terbaik biosintesis $\mathrm{ZnO}$ ditentukan lebih lanjut dengan hasil analisis instrumen XRD.

\section{Struktur kristal ZnO}

Data hasil analisis struktur kristal menggunakan instrumen XRD untuk semua sampel selanjutnya diolah dengan program Match! 3 seperti pada Gambar $5 a$ dan 5b. Pola difraksi $\mathrm{ZnO}$ standar dikonfirmasi dengan data crystallography open database (COD) sebagai referensi database kisi kristal yaitu 96-2300113 (Heidrun \& Hans, 2006) sehingga diperoleh bidang kristalografinya yang ditetapkan dengan tiga Indeks Miller yaitu h, k, dan I; $2 \theta$; dan tinggi puncak yang hasilnya dapat dlihat pada Tabel 3 . Data-data tersebut dapat digunakan untuk menghitung lebar puncak pada setengah tinggi puncak maksimum (FWHM/full with at half maximum) (Tabel 3).

Gambar 5a menunjukkan grafik pola difraksi $\mathrm{ZnO}$ dari biosintesis ekstrak Sargassum sp. pada kondisi larutan $\mathrm{pH} 8,9$, 10, dan 11 (5a-d) yang memiliki kristalinitas $\mathrm{ZnO}$ paling baik. Puncak-puncak yang terbentuk memiliki sudut $2 \theta$ yang hampir sama dengan $\mathrm{ZnO}$ standar. Sedangkan pola difraksi $\mathrm{ZnO}$ dari biosintesis ekstrak Sargassum sp. pada kondisi larutan $\mathrm{pH} 12$ berbeda. Dengan bertambahnya $\mathrm{pH}$ larutan prekursor dalam proses biosintesis di mana semakin tinggi konsentrasi atau molaritas $\mathrm{NaOH}$ maka semakin banyak terbentuk endapan dalam larutan tersebut. Penambahan agen pengendap secara terus menerus menyebabkan larutan menjadi jenuh dan koloidal menjadi berwarna putih susu. Pola difraksi $\mathrm{ZnO}$ dari biosintesis ekstrak Sargassum sp. pada kondisi larutan pH 12 berbeda dikarenakan banyaknya pengotor dengan munculnya puncakpuncak yang bukan puncak $\mathrm{ZnO}$. Hal ini diduga pada kondisi $\mathrm{pH}$ larutan 12 penambahan agen pengendap larutan $\mathrm{NaOH}$ terlalu banyak sehingga larutan telah melewati titik jenuhnya. Menurut Rosyidah et al. (2017) kemurnian $\mathrm{ZnO}$ menjadi berkurang apabila kondisi larutan terlalu jenuh.

Gambar 5b menunjukkan $\mathrm{ZnO}$ dari biosintesis ekstrak Padina sp. yang tidak membentuk kristal ZnO pada pH 8 (5-a) dan 11 (5-b), kecuali pH 9 (5-b). Pada $\mathrm{pH} 8$ dan 11 puncak-puncak yang terbentuk bukanlah merupakan puncak $\mathrm{ZnO}$. Hal ini disebabkan terjadi kecenderungan aglomerasi karena energi permukaan tinggi yang umumnya terjadi ketika sintesis dilakukan dalam larutan dan juga terjadi densifikasi yang menghasilkan ruang sempit antar partikel (Moghaddam et al., 2017).

Berdasarkan Tabel 3 hampir seluruh sampel memiliki puncak yang tidak jauh berbeda dan menunjukkan $\mathrm{ZnO}$ yang dihasilkan berstruktur kristal heksagonal wurtzit. Puncak dengan intensitas tertinggi pada $\mathrm{ZnO}$ biosintesis ekstrak Sargassum sp. dan 


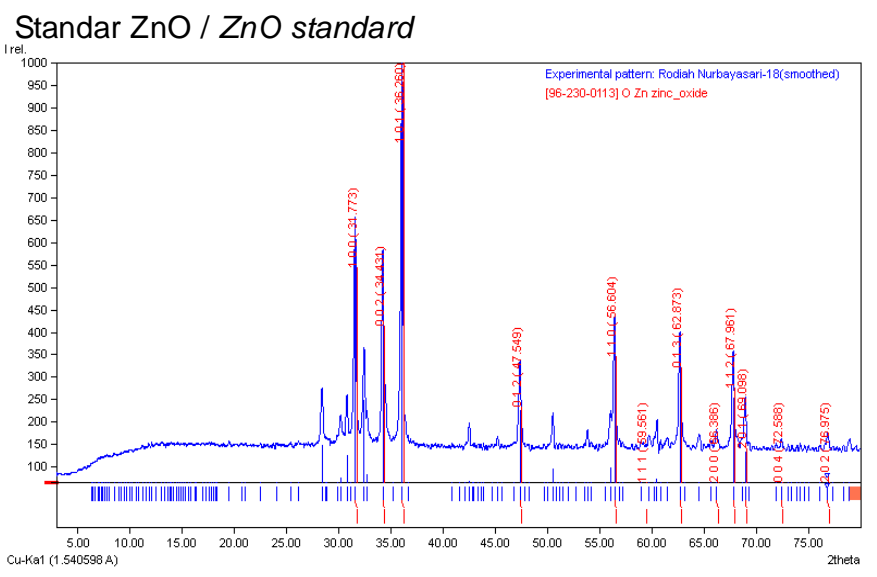

ZnO ekstrak Sargassum sp./ ZnO - Sargassum sp. extract

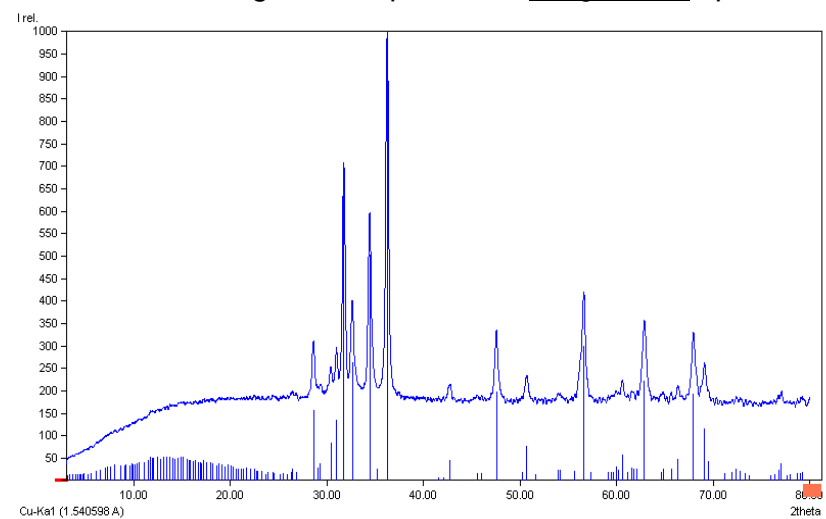

(a) $\mathrm{pH} 8$

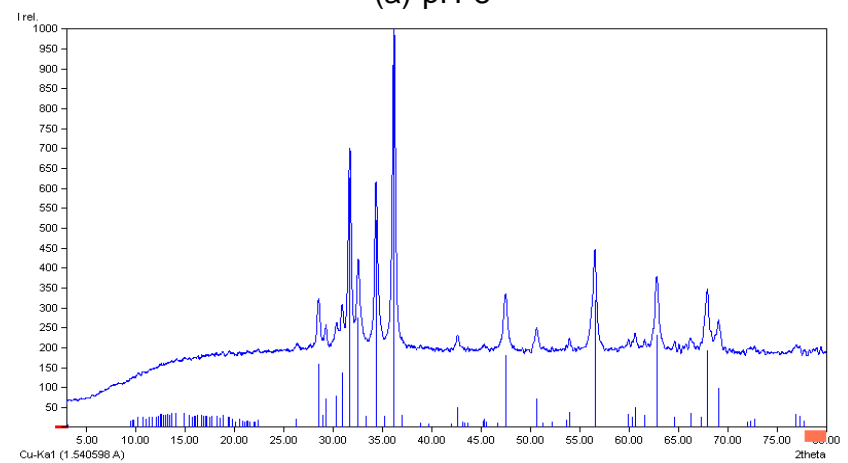

(c) $\mathrm{pH} 10$

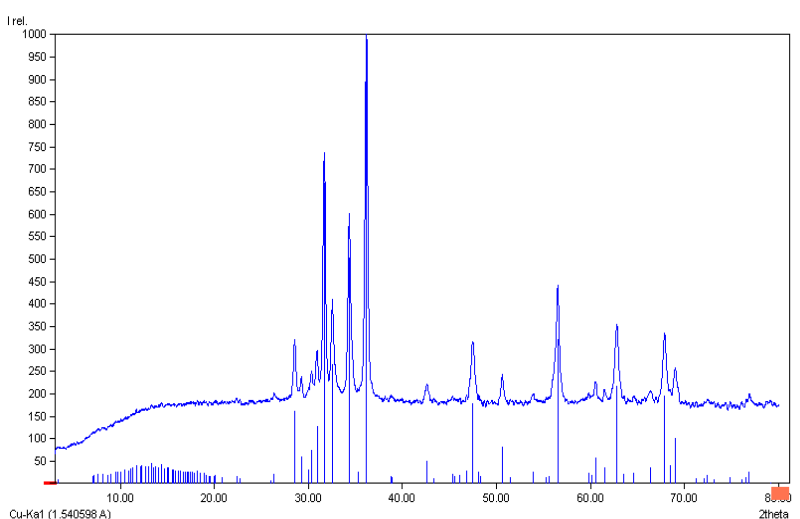

(b) $\mathrm{pH} 9$

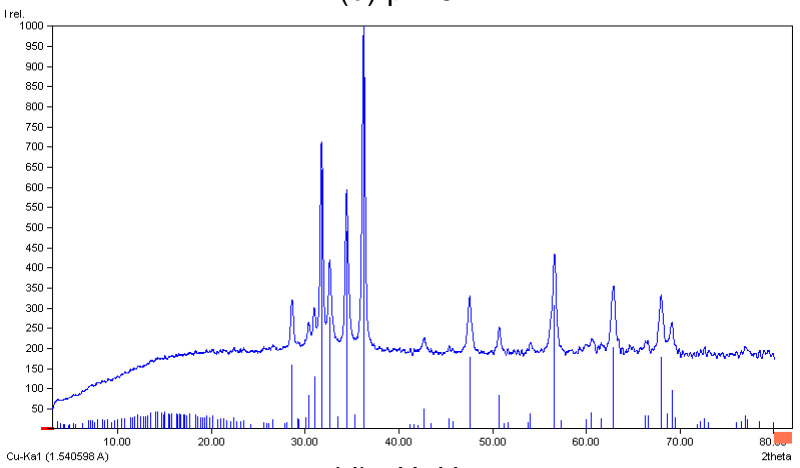

(d) $\mathrm{pH} 11$

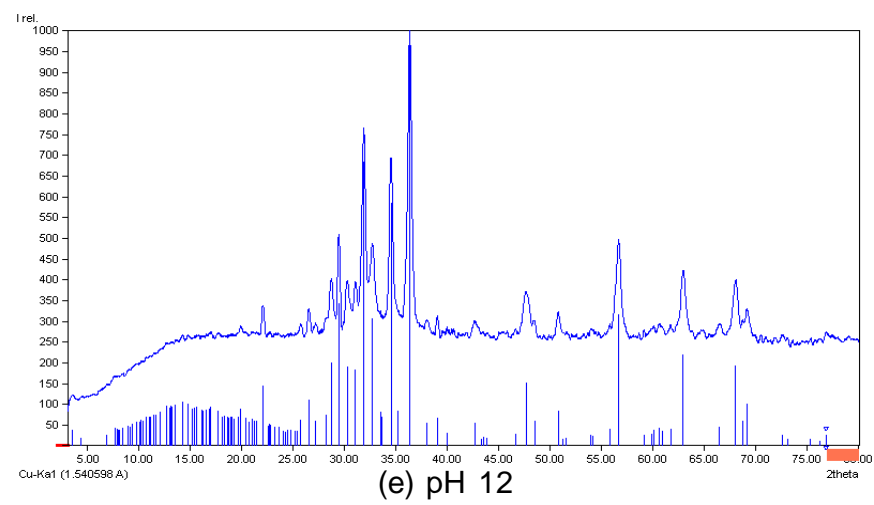

Gambar 5a. Pola Difraksi standar ZnO dan ZnO dari biosintesis ekstrak Sargassum sp. pada variasi $\mathrm{pH}$ Figure 5a. Difraction pattern of $\mathrm{ZnO}$ standard, and $\mathrm{ZnO}$ of biosynthesized Sargassum sp. extract at various $\mathrm{pH}$ 


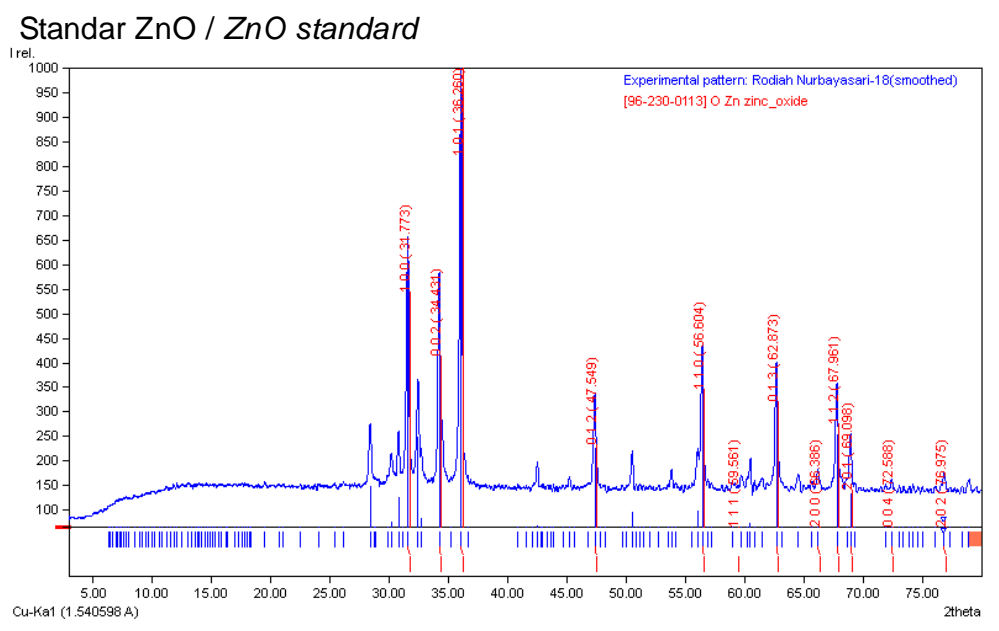

ZnO ekstrak Padina sp./ ZnO - Padina sp. extract

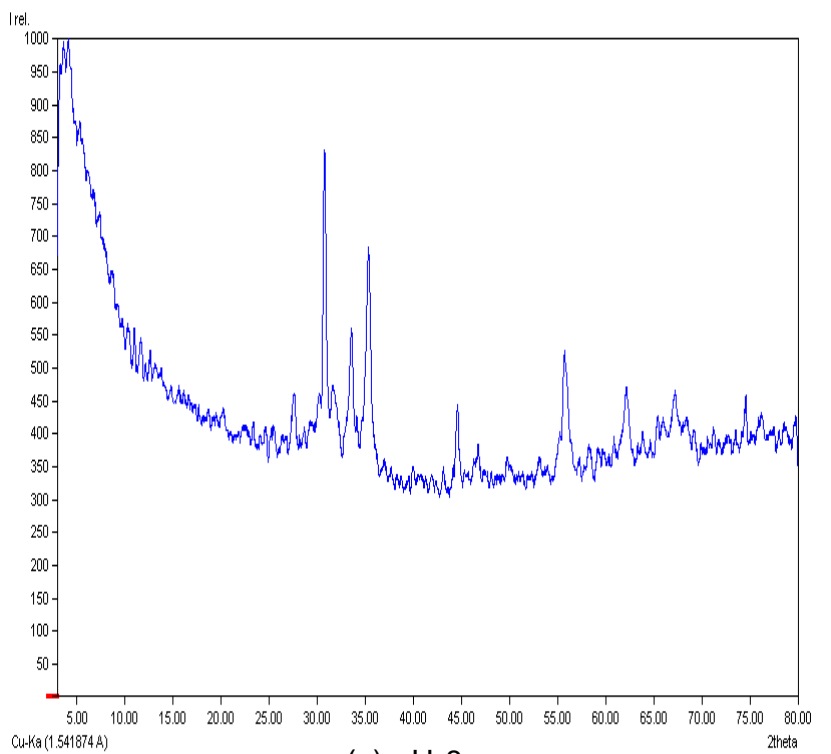

(a) $\mathrm{pH} 8$

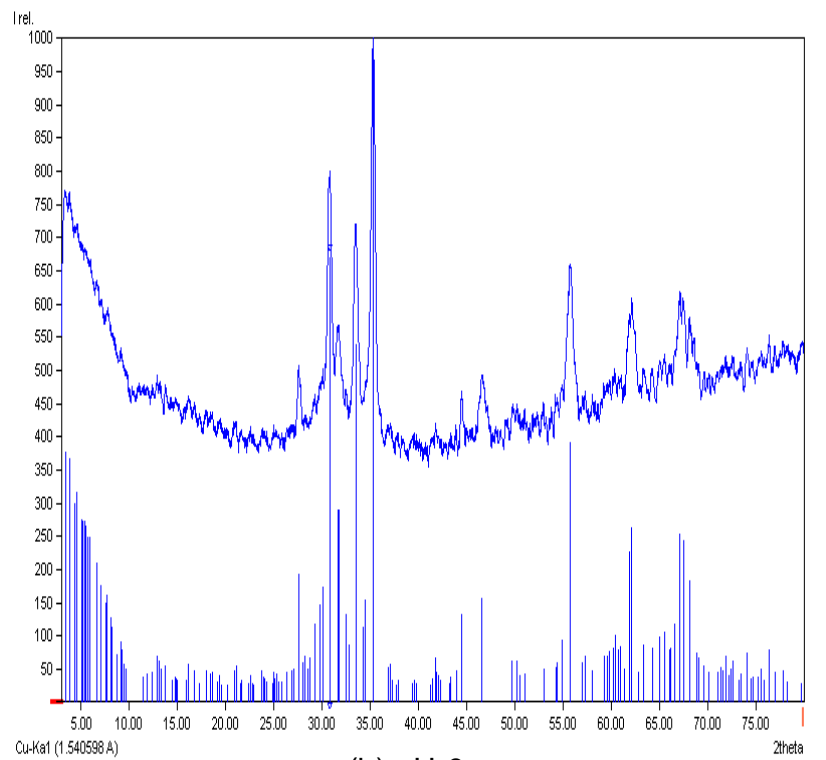

(b) $\mathrm{pH} 9$

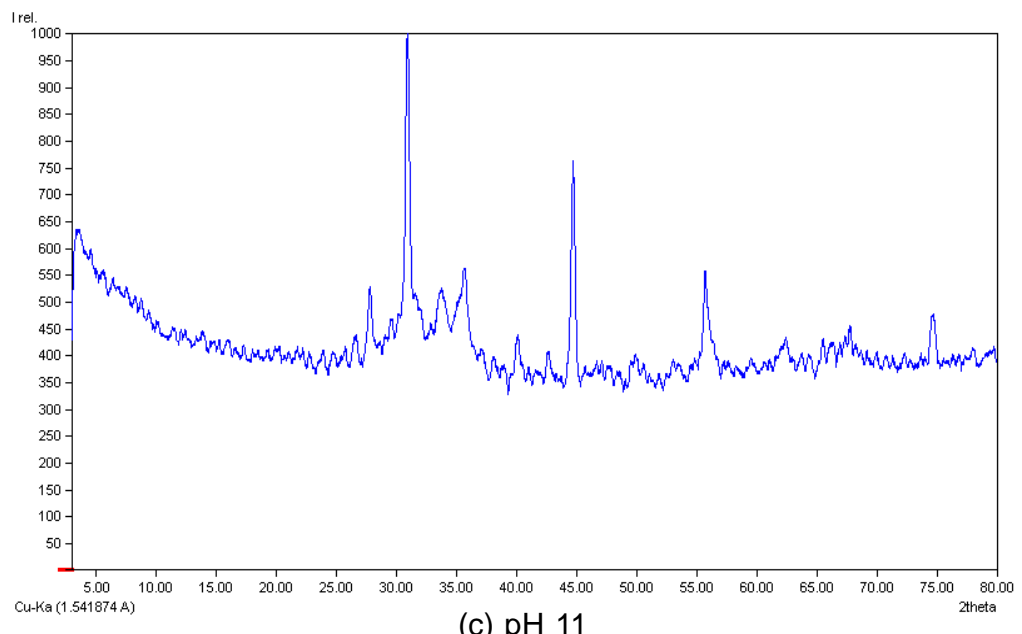

Gambar 5b. Pola Difraksi standar ZnO dan ZnO dari biosintesis ekstrak dan Padina sp. pada variasi $\mathrm{pH}$ Figure 5b. Difraction pattern of $\mathrm{ZnO}$ standard and $\mathrm{ZnO}$ of biosynthesized Padina sp. extract at various $\mathrm{pH}$ 
Tabel 3. Puncak $2 \theta$ kristal $\mathrm{ZnO}$

Table 3. $2 \theta$ peak of crystal $\mathrm{ZnO}$

\begin{tabular}{|c|c|c|c|c|}
\hline No & Sampel/Sample & $\begin{array}{c}\text { Arah orientasi/ } \\
\text { Orientation direction }\end{array}$ & $2 \theta\left({ }^{\circ}\right)$ & $\begin{array}{c}\text { Tinggi puncak/ } \\
\text { Peak height }\end{array}$ \\
\hline \multirow{11}{*}{1} & Standar $\mathrm{ZnO} / \mathrm{ZnO}$ standard & -100 & 31,60 & 591,1 \\
\hline & & -2 & 34,26 & 505,0 \\
\hline & & -101 & 36,09 & 1000,0 \\
\hline & & -12 & 47,38 & 225,4 \\
\hline & & -110 & 56,45 & 345,1 \\
\hline & & -13 & 62,71 & 305,4 \\
\hline & & -200 & 66,21 & 45,9 \\
\hline & & -112 & 67,81 & 254,2 \\
\hline & & -201 & 68,95 & 132,9 \\
\hline & & -4 & 72,41 & 28,4 \\
\hline & & -202 & 76,85 & 45,3 \\
\hline \multirow[t]{56}{*}{2} & ZnO ekstrak Sargassum sp./ZnO - Sargassum sp. extract & & & \\
\hline & $\mathrm{pH} 8$ & -100 & 31,77 & 640,0 \\
\hline & & -2 & 34,44 & 503,4 \\
\hline & & -101 & 36,26 & 1000,0 \\
\hline & & -12 & 47,57 & 196,6 \\
\hline & & -110 & 56,62 & 299,8 \\
\hline & & -13 & 62,90 & 221,2 \\
\hline & & -200 & 66,37 & 46,1 \\
\hline & & -112 & 67,97 & 193,6 \\
\hline & & -201 & 69,12 & 115,0 \\
\hline & & -4 & 72,41 & 25,5 \\
\hline & & -202 & 77,07 & 37,1 \\
\hline & $\mathrm{pH} 9$ & -100 & 31,69 & 670,5 \\
\hline & & -2 & 34,35 & 503,4 \\
\hline & & -101 & 36,17 & 1000,0 \\
\hline & & -12 & 47,47 & 177,3 \\
\hline & & -110 & 56,53 & 321,1 \\
\hline & & -13 & 62,81 & 216,3 \\
\hline & & -200 & 66,34 & 35,3 \\
\hline & & -112 & 67,89 & 193,9 \\
\hline & & -201 & 69,02 & 101,0 \\
\hline & & -4 & 72,43 & 17,6 \\
\hline & & -202 & 76,90 & 26,2 \\
\hline & $\mathrm{pH} 10$ & -100 & 31,73 & 626,4 \\
\hline & & -2 & 34,39 & 520,1 \\
\hline & & -101 & 36,21 & 1000,0 \\
\hline & & -12 & 47,51 & 179,6 \\
\hline & & -110 & 56,56 & 318,3 \\
\hline & & -13 & 62,84 & 230,8 \\
\hline & & -200 & 66,25 & 35,5 \\
\hline & & -112 & 67,95 & 192,3 \\
\hline & & -201 & 69,09 & 97,0 \\
\hline & & -4 & 72,39 & 16,5 \\
\hline & & -202 & 76,96 & 32,7 \\
\hline & $\mathrm{pH} 11$ & -100 & 31,76 & 642,2 \\
\hline & & -2 & 34,43 & 491,3 \\
\hline & & -101 & 36,25 & 1000,0 \\
\hline & & -12 & 47,55 & 17,0 \\
\hline & & -110 & 56,60 & 306,3 \\
\hline & & -13 & 62,89 & 202,7 \\
\hline & & -200 & 66,29 & 31,6 \\
\hline & & -112 & 67,97 & 178,6 \\
\hline & & -201 & 69,13 & 94,9 \\
\hline & & -4 & 72,20 & 18,2 \\
\hline & & -202 & 76,92 & 31,5 \\
\hline & $\mathrm{pH} 12$ & -100 & 31,89 & 685,0 \\
\hline & & -2 & 34,54 & 585,6 \\
\hline & & -101 & 36,36 & 1000,0 \\
\hline & & -12 & 47,66 & 152,5 \\
\hline & & -110 & 56,69 & 315,5 \\
\hline & & -13 & 62,97 & 218,4 \\
\hline & & -200 & 66,51 & 44,7 \\
\hline & & -112 & 68,07 & 191,4 \\
\hline & & -201 & 69,16 & 99,8 \\
\hline & & -4 & 72,59 & 25,3 \\
\hline & & -202 & 76,87 & 25,1 \\
\hline \multirow[t]{13}{*}{3} & ZnO ekstrak Padina sp./ZnO - Padina sp. extract & & & \\
\hline & $\mathrm{pH} 8$ & - & - & - \\
\hline & $\mathrm{pH} 9$ & -100 & 30,83 & 670,5 \\
\hline & & -2 & 34,31 & 113,6 \\
\hline & & -101 & 35,33 & 1000,0 \\
\hline & & -12 & 46,61 & 156,1 \\
\hline & & -110 & 56,53 & 321,1 \\
\hline & & -13 & 62,85 & 44,0 \\
\hline & & -200 & 66,18 & 82,2 \\
\hline & & -112 & 68,07 & 182,1 \\
\hline & & -201 & 68,85 & 74,2 \\
\hline & & -4 & 72,39 & 50,0 \\
\hline & & -202 & 76,93 & 45,0 \\
\hline
\end{tabular}


Padina sp. pada hampir semua sampel diperoleh pada bidang 101 dan sudah sesuai dengan ZnO standar. Pola difraksi yang dihasilkan juga hampir sama dengan yang dilaporkan oleh Kumar dan Rani (2013); Nagarajan dan Kuppusamy (2013); dan Azizi et al. (2014).

Berdasarkan puncak tertinggi pada kisaran sudut difraksi antara 36,17-36,36을 indeks miller 101 maka nilai FWHM dan ukuran partikel dapat dihitung dengan menggunakan persamaan Debye-Scherrer, dengan hasil pada Tabel 4 . Nilai $k$ yang digunakan sebesar 0,91 sesuai dengan bentuk kristal $\mathrm{ZnO}$ heksagonal dan puncak tertinggi di 101 (Nagarajan \& Kuppusamy, 2013). Ukuran partikel ZnO biosintesis dengan ekstrak Sargassum sp. berkisar antara 48,27$54,49 \mathrm{~nm}$ dan $\mathrm{ZnO}$ biosintesis dengan ekstrak Padina $\mathrm{sp}$. sebesar $38,30 \mathrm{~nm}$. Perbedaan hasil pengukuran partikel antara instrumen PSA dan persamaan DebyeScherrer dikarenakan persamaan Debye-Scherrer digunakan untuk menduga ukuran kristalin dalam material, bukan ukuran partikel. Satu partikel terdiri dari sejumlah kristalin yang kecil-kecil. Ukuran kristalin ditentukan berdasarkan pelebaran puncak difraksi sinar-X yang muncul. Jika partikel berukuran nanometer, biasanya satu partikel hanya mengandung satu kristalin. Dengan demikian, ukuran kristalinitas yang diprediksi dengan persamaan Debye-Schreer juga merupakan ukuran partikel. Namun pada penelitian ini hasil pengukuran dengan instrumen PSA menunjukkan partikel masih berukuran mikrometer, belum nanometer sehingga ukuran kristalin yang diperoleh menggunakan persamaan Debye-Scherrer tidak menunjukkan ukuran partikel.

Hasil perhitungan ukuran partikel yang diperoleh berbeda dengan yang dilaporkan Kumar dan Rani
(2013); Nagarajan dan Kuppusamy (2013); dan Azizi et al. (2014). Hal tersebut diduga karena referensi yang digunakan pada program Matcth! 3 berbeda. Penelitian ini menggunakan $\mathrm{ZnO}$ standar Sigma aldrich yang kemudian data hasil analisis tersebut didekatkan dengan referensi yang ada yaitu COD 96-230-0113. Nagarajan dan Kuppusamy (2013) menggunakan referensi JCPDS (Joint Committee on Powder Diffraction Standard) card No 89-1397 dan Azizi et al. (2014) menggunakan referensi JCPDS card No 361451.

Biosintesis $\mathrm{ZnO}$ dari ekstrak rumput laut coklat Sargassum sp. dan Padina sp. telah berhasil dilakukan dan menghasilkan perlakuan terbaik pada pH larutan 10 untuk ekstrak Sargassum sp. dan $\mathrm{pH} 9$ untuk ekstrak Padina sp. dengan konsentrasi masingmasing ekstrak adalah 5\% (v/v) terhadap prekursor zink nitrat $10 \mathrm{mM}$. Ukuran partikel $\mathrm{ZnO}$ biosintesis dari ekstrak rumput laut coklat Sargassum sp. pada $\mathrm{pH} 10$ dan Padina sp. pada $\mathrm{pH} 9$ yang diperoleh dari hasil analisis PSA berturut-turut adalah 1.521,71 dan $655,91 \mathrm{~nm}$. Analisis morfologi menghasilkan $\mathrm{ZnO}$ dari ekstrak rumput laut coklat Sargassum sp. pada pH 10 yang memiliki \%massa Zn 95,98 dan O 4,02\% sedangkan Padina sp. pada pH 9 memiliki \% massa $94,67 \%$ dan O 5,33\%. Struktur kristal juga sudah terbentuk pada $\mathrm{ZnO}$ biosintesis dari ekstrak rumput laut coklat Sargassum sp. pada pH 10 dan Padina sp. pada pH 9 tersebut. Penelitian Sari, Nurhasni, dan Yaqin (2017) juga menghasilkan ZnO dari biosintesis ekstrak Sargassum sp. 5\% (v/v) dengan prekursor zink nitrat $0,1 \mathrm{M}$ dan diklasinasi pada suhu $400^{\circ} \mathrm{C}$ yang memiliki ukuran $607 \mathrm{~nm}$ dan \%massa unsur $\mathrm{Zn} \mathrm{89,19 \%} \mathrm{dan} \mathrm{O}$ $10,74 \%$.

Tabel 4. FWHM dan ukuran partikel $\mathrm{ZnO}$

Table 4. FWHM and particle size of $\mathrm{ZnO}$

\begin{tabular}{|c|c|c|c|c|c|c|c|c|}
\hline \multirow{3}{*}{ Zno } & \multirow{3}{*}{$\begin{array}{c}201 \\
\text { Derajat/ } \\
\text { Degree }\end{array}$} & \multirow{3}{*}{$\begin{array}{c}2 \theta 2 \\
\text { Derajat/ } \\
\text { Degree }\end{array}$} & \multicolumn{2}{|c|}{ FWHM (B) } & \multicolumn{3}{|c|}{$\begin{array}{l}\text { Puncak Tertinggi// } \\
\text { The Highest Peak }\end{array}$} & \multirow{3}{*}{$\begin{array}{c}\text { Ukuran } \\
\text { Partikel/ } \\
\text { Particle } \\
\text { Size }(\mathrm{nm})\end{array}$} \\
\hline & & & \multirow{2}{*}{$\begin{array}{l}\text { Derajat/ } \\
\text { Degree }\end{array}$} & \multirow{2}{*}{$\begin{array}{l}\text { Radian/ } \\
\text { Radians }\end{array}$} & $2 \theta$ & $\theta$ & $\begin{array}{l}\text { Radian/ } \\
\text { Radians }\end{array}$ & \\
\hline & & & & & \multicolumn{2}{|c|}{ Derajat/Degree } & $\begin{array}{l}\text { Radian/ } \\
\text { Radians }\end{array}$ & \\
\hline S-pH 8 & 36.10 & 36.42 & 0.1600 & 0.002794 & 36.26 & 18.13 & 0.316556 & 0.00 \\
\hline S-pH 9 & 36.02 & 36.33 & 0.1550 & 0.002706 & 36.17 & 18.09 & 0.315770 & 0.00 \\
\hline S-pH 10 & 36.04 & 36.39 & 0.1750 & 0.003056 & 36.21 & 18.11 & 0.316119 & 0.00 \\
\hline S-pH 11 & 36.08 & 36.42 & 0.1700 & 0.002968 & 36.25 & 18.13 & 0.316468 & 0.00 \\
\hline S-pH 12 & 36.20 & 36.52 & 0.1600 & 0.002794 & 36.36 & 18.18 & 0.317429 & 0.00 \\
\hline P-pH 9 & 35.10 & 35.54 & 0.2200 & 0.003841 & 35.33 & 17.67 & 0.308437 & 0.00 \\
\hline
\end{tabular}

Ket./Note::

S-pH 8: Ekstrak Sargassum sp. pada pH 8/Sargassum sp. extract at $\mathrm{pH} 8$

P-pH 9: Ekstrak Padina sp. pada pH 9/Padina sp. extract at $\mathrm{pH} 9$ 


\section{KESIMPULAN}

Gugus fungsi yang berperan dalam proses reduksi kation $\mathrm{Zn}^{2+}$ membentuk nanopartikel $\mathrm{ZnO}$ adalah hidroksil dan sulfat polisakarida sedangkan kestabilan nanopartikel adalah protein. Perlakuan terbaik pada penelitian ini adalah $\mathrm{ZnO}$ dari biosintesis ekstrak Sargassum sp. pada perlakuan pH larutan 10 dan $\mathrm{ZnO}$ dari biosintesis ekstrak Padina sp.pada $\mathrm{pH} 9$ dengan konsentrasi masing-masing ekstrak 5\% (v/v), meskipun dari hasil pengukuran belum mencapai ukuran nanopartikel. Diperlukan penelitian lanjut untuk mendapatkan $\mathrm{ZnO}$ dengan ukuran partikel sesuai kriteria nanopartikel.

\section{DAFTAR PUSTAKA}

Ashajyothi, C. (2014). Antibacterial activity of biogenic zinc oxide nanoparticals synthesis from Enterococcus faecalis. International Journal of Chemtech Reasearch. 6(5): 3131-3136.

American Society for Testing and Materials (ASTM). (2007). ASTM D422-63(2007)e2, Standard Test Method for Particle-Size Analysis of Soils. ASTM International, West Conshohocken, PA 19428-2959, United States. https://www.astm.org/Standards/ D422.htm. Diakses pada tanggal 10 Juli 2017.

American Society for Testing and Materials (ASTM). (2008). E1131-08, Standard Test Method for Compositional Analysis by Thermogravimetry. ASTM International, West Conshohocken, PA 19428-2959, United States. https://www.astm.org/Standards/ E1131.htm. Diakses pada tanggal 10 Juli 2017.

American Society for Testing and Materials (ASTM). (2010). ASTM D6348-03(2010), Standard Test Method for Determination of Gaseous Compounds by Extractive Direct Interface Fourier Transform Infrared (FTIR) Spectroscopy. ASTM International, West Conshohocken, PA 19428-2959, United States. https://www.astm.org/Standards/D6348.htm. Diakses pada tanggal 10 Juli 2017.

American Society for Testing and Materials (ASTM). (2012). ASTM E1508 - 12a, Standard Guide for Quantitative Analysis by Energy-Dispersive Spectroscopy. ASTM International, West Conshohocken, PA 19428-2959, United States. https://www.astm.org/Standards/E1508.htm. Diakses pada tanggal 10 Juli 2017.

American Society for Testing and Materials (ASTM). (2013). ASTM D3906 - 03(2013), Standard Test Method for Determination of Relative X-ray Diffraction Intensities of Faujasite-Type Zeolite-Containing Materials. ASTM International, West Conshohocken, PA 19428-2959, United States. https://www.astm.org/ Standards/D3906.htm. Diakses pada tanggal 10 Juli 2017

Azizi, S., Mansor, B.A., Farideh, N., \& Rosfarizan, M. (2014). Green biosynthesis and characterization of zinc oxide nanoparticles using brown marine macroalga
Sargassum muticum aqueous extract. Materials Letters. 116: 275-277.

Barros, F.C.N., Draulio, C.da S., Venicios, G.S., Jeanny, S. M., Judith, P.A.F., Ana, L.P.F., \& Regina, C.M.de P. (2013). Structural characterization of polysaccharide obtained from red seaweed Gracilaria caudata (J Agardh). Carbohydrate Polymers. 92: 598-603.

Bian, S.W., Mudunkotuwa, I.A., Rupasinghe, T., \& Grassian, V.H. (2011). Aggregation and dissolution of $4 \mathrm{~nm} \mathrm{ZnO}$ nanoparticles in aqueous environments: influence of $\mathrm{pH}$, ionic strength, size, and adsorption of humic acid. Langmuir. 27: 6059-6068.

Christiaen, D., \& Bodard, M. (1983). Infrared spectroscopy of agar ûlms from Gracilaria verrucosa (Huds.) Papenfuss. Botanica Marina. 26(9): 425-427.

Dumur, F., Guerlin, A., Dumas, E., Bertin, D., Gigmes, D., \& Mayer, C. (2011). Controlled spontaneous generation of gold nanoparticles assisted by dual reducing and capping agents. Gold Bulletin. 44(2):119-137.

Ehsan, S., \& Sajjad, M. (2017). Bioinspired Synthesis of Zinc Oxide Nanoparticle and its Combined Efficacy with Different Antibiotics against Multidrug Resistant Bacteria. Journal of Biomaterials and Nanobiotechnology. 8: 159-17.

Elumalai, K., \& Velmurugan, S. 2015. Applied surface science green synthesis, characterization and antimicrobial activities of zink oxide nanoparticles from the leaf extract of Azadirachta indica (L.). Applied Surface Science. 345: 329-336.

Fawcett, D., Verduin, J.J, Shah, M., Sharma, S.B., \& Poinern, G.E.J. (2017). Review of Current Research into the Biogenic Synthesis of Metal and Metal Oxide Nanoparticles via Marine Algae and Seagrasses. Journal of Nanoscience. Article ID 8013850: 1-15.

Foliatini, F., Yulizar, Y., \& Hafizah, M.A.E. (2015). The Synthesis of alginate-capped silver nanoparticles under microwave irradiation. Journal of Mathematical and Fundamental Sciences. 47(1): 31-50.

Gunalan, S., Sivaraj, R., \& Rajendran, V. (2011). Green synthesis of zinc oxide nanoparticles by aloe barbadensis miller leaf extract: structure and optical properties. Materials Research Bulletin. 46(12): 2560-2566.

Heidrun, S., \& Hans, A. (2006). High-pressure X-ray investigation of zincite $\mathrm{ZnO}$ single crystals using diamond anvils with an improved shape. Journal of Applied Crystallography. 39(2): 169-175.

Jayaraman, J.D., Sigamani, S., Venkatachalam, H., \& Ramamurthy, D. 2016. Extraction and Purification of Sulfated Polysaccharide from Brown Algae and Its Efficacy in Preventing Blood Clotting. Asian Journal of Bilogical and Life Sciences. 5(3): 237-244.

Jegan, A., Ramasubbu, A., Karunakaran, K., \& Vasanthkumar, S. (2012). Synthesis and characterization of zinc oxide-agar-agar nanocomposite. International Journal of Nano Dimension. 2(3): 171-176.

Krishnaiah, D., Sarbatly, R., Prasad, D.M.R., \& Bono, A. (2008). Mineral content of some seaweeds from 
Sabah's South China Sea. Asian Journal of Scientific Research. 1(2): 166-170.

Kumar, H., \& Rani, R. (2013). Structural and Optical Characterization of $\mathrm{ZnO}$ Nanoparticles Synthesized by Microemulsion Route. International Letters of Chemistry, Physics and Astronomy. 14: 26-36.

Masakke ,Y., Sulfikar, \& Muhaedah, R. (2015). Biosynthesis of Silver nanoparticles using methanol extract of mangosteen leaves (Garcinia mangostana L.). Jurnal Sainsmat. 4(1): 28-41.

Mata, Y.N., Torres, E., Blázquez, M.L., Ballester, A., González, F., \& Muñoz, J.A. (2009). Gold(III) biosorption and bioreduction with the brown alga Fucus vesiculosus. Journal of Hazardous Materials. 166(2-3): 612-618.

Manivannan, K., Devi, G.K., Thirumaran, G., \& Anantharaman, P. (2008). Mineral Composition of Marine Macroalge from Mandapam Coastal Regions; Southeast Coast of India. American-Eurasian Journal of Botany. 1 (2): 58-67. ISSN 1995-8951.

Melo, M.R.S., Feitosa, J.P.A., Freitas, A.L.P., \& de Paula, R.C.M. (2002). Isolation and characterization of soluble sulfated polysaccharide from the red seaweed Gracilaria cornea. Carbohydrate Polymers. 49(4): 491-498.

Moghaddam, A.B., Moniri, M., Azizi, S., Raha Abdul Rahim, R.A., Arbakariya Bin Ariff, A.B., Wan Zuhainis Saad, W.Z., Namvar, F., Mohammad Navaderi, M., \& Mohamad, R. (2017). Biosynthesis of ZnO Nanoparticles by a New Pichia kudriavzevii Yeast Strain and Evaluation of Their Antimicrobial and Antioxidant Activities. Molecules. 22(6): 872:890.

Mohanraj, V., \& Chen, Y. (2007). Nanoparticles - A Review. Tropical Journal of Pharmaceutical Research. 5(1): 561-573.

Nagajyothi, P.C., Tran, N.M.A, Sreekanth, T.V.M., Jae-il, L., Dong, J.L., \& Lee, K.D. (2013). Green route biosynthesis: Characterization and catalytic activity of ZnO nanoparticles. Materials Letters. 108: 160-163.

Nagarajan, S. \& Kuppusamy, K.A. (2013). Extracellular synthesis of zinc oxide nanoparticle using seaweeds of gulf of Mannar, India. Journal of Nanobiotechnology. 11: 39.

Nurmawati, M. (2007). Analisis derajat kristalinitas, ukuran kristal dan bentuk partikel mineral tulang manusia berdasarkan variasi umur dan jenis tulang. [Skripsi]. Depok (ID) : Universitas Indonesia

Peletiri, C., Matur, B.M., lhongbe, J.C., \& Okoye, M. (2012). The Effect of Azadirachta indica (Neem Tree) On Human Plasmodiasis: The Laboratory Perspective. Global Research Journal of Medical Sciences. 2(1): 013 - 017.

Perwitasari, F.L.R, Aminatun, \& Sumarsih, S. (2012). Karakterisasi in vitro dan in vivo komposit alginatpoli vinil alkohol-zno nano sebagai wound dressing antibakteri. Prosiding Seminar Fisika Terapan III. Departemen Fisika-FST-Universitas Airlangga, Surabaya. ISBN:978-979-17494-2-8.
Pongpiachan, S. (2014). FTIR Spectra of Organic Functional Group Compositions in PM2.5 Collected at Chiang-Mai City, Thailand during the Haze Episode in March 2012. Journal of Applied Sciences. 14:29672977.

Purkait, P.K., Jagannath, R., Saikat, M., \& Mouha, G.C. (2015). Green synthesis of zinc oxide nanoparticle-A review. Scientifif Voyage. 1(2): 32-46.

Rosyidah, N., Purwaningsih, S.Y., \& Darminto. (2017). Sintesis Nanopartikel ZnO dengan Metode Kopresipitasi. Jurnal Teknik Pomits: 1-7. http:// digilib.its.ac.id/public/ITS-paper-36911-1110100003paper.pdf. Diakses pada tanggal 26 September 2017.

Ristian, I. (2013). Kajian pengaruh konsentrasi perak nitrat $\left(\mathrm{AgNO}_{3}\right)$ terhadap ukuran nanopartikel perak. Skripsi. Jurusan Kimia Fakultas Matematika dan IImu Pengetahuan Alam Universitas Negeri Semarang. $86 \mathrm{p}$.

Sakthivel, M., Deivasigamani, B., Rajasekar, T., Kumaran, S. \& Alagappan, K.M. (2015). Immunostimulatory Effects of Polysaccharide Compound from Seaweed Kappaphycus alvarezii on Asian seabass (Lates calcarifer) and it's Resistance against Vibrio parahaemolyticus. Journal of Marine Biology \& Oceanography. 4(2): 1-9.

Sangeetha N. \& Kumarghru A.K. (2013). Extra Cellular Synthesis of Zinc Oxide Nanoparticle Using Seaweeds of Gulf of Mannar, India. Journal of Nano Biotechnology. 11: 39.

Sari, R.N., Nurhasni, \& Yaqin, M.A. 2017. Sintesisi Nanopartikel ZnO Ekstrak Sargassum sp. dan Karakteristik Produknya. Jurnal Pengolahan Hasil Perikanan Indonesia. 20(2): 238-254.

Selvarajan, E., \& Mohanasrinivasan, V. (2013). Biosynthesis and characterization of $\mathrm{ZnO}$ nanoparticles using Lactobacillus plantarum VITES07. Materials Letters. 112: 180-182.

Shah, M., Fawcett, D., Sharma, S., Tripathy, S.K., \& Poinern, G.E.J. (2015). Green synthesis of metallic nanoparticles via biological entities. Materials. 8(11): 7278-7308.

Sharma, A., Sharma, S., \& Sharma, K. (2015). Algae as crucial organisms in advancing nanotechnology: a systematic review. Journal Applied Phycology. 1: 116.

Sholehah, A. (2015). Sintesis nanostruktur seng oksida $(\mathrm{ZnO})$ berketeraturan tinggi dengan metode kimiawi basah untuk aplikasi sel surya tersensitasi zat pewarna. Disertasi. Program Studi Teknik Metalurgi dan Material, Fakultas Teknik, Universitas Indonesia, Depok. 128 p.

Tiwari B.K., \& Declan, J.T. (2015). Seaweed Sustainability: Food and Non-Food Applications Chapter 11: 288-313. Elsevier Inc.

Vernardou, D., Kenanakis, G., Couris, S., Kodoumas, E., Kymakis, E., \& Katsarakis, N. (2007). pH effect on the morfology of $\mathrm{ZnO}$ nanostructures grown with aqueous chemical growth. Thin Solid Flms. 515(24): 8764-8767. 
Visinescu. D., Greta, P., Alina, T.,\& Oana, C. 2012. Polysaccharides route: a new green strategy for metal oxides synthesis. Environmental Chemistry for a Sustainable World. 1(5): 119-169.

Wang, M., Ye, C.H., Zhang, Y., Hua, G.M., Wang, H.X., Kong, M.G., \& Zhang, L.D. (2006). Synthesis of wellaligned $\mathrm{ZnO}$ nanorod arrays with high opcital property via a low temperature solution method. Journal of Crystal Growth. 291(2): 334-339.

Zelechowska, K. (2014). Methods of ZnO nanoparticles synthesis. BioTechnologia. 95(2): 150-159.

Zhang, J., Lingdong, Jialu, Huilan, Chunsheng, \& Chunhua. (2002). Control of $\mathrm{ZnO}$ morphology via a simple solution route. Chemistry of Materials. 14: 4172-4177. 